Summer 2013

\title{
Transnational Corporations' Outward Expression of Inward Self- Constitution: The Enforcement of Human Rights by Apple, Inc.
}

Larry Cata Backer

Pennsylvania State University, Icb11@psu.edu

Follow this and additional works at: https://www.repository.law.indiana.edu/ijgls

Part of the Constitutional Law Commons, Human Rights Law Commons, International Law Commons, and the Transnational Law Commons

\section{Recommended Citation}

Backer, Larry Cata (2013) "Transnational Corporations' Outward Expression of Inward Self-Constitution: The Enforcement of Human Rights by Apple, Inc.," Indiana Journal of Global Legal Studies: Vol. 20 : Iss. 2 , Article 10.

Available at: https://www.repository.law.indiana.edu/ijgls/vol20/iss2/10

This Symposium is brought to you for free and open access by the Law School Journals at Digital Repository @ Maurer Law. It has been accepted for inclusion in Indiana Journal of Global Legal Studies by an authorized editor of Digital Repository @ Maurer Law. For more information, please contact rvaughan@indiana.edu.

JEROME HALL LAW LIBRARY

INDIANA UNIVERSITY

Maurer School of Law
Blooming ton 


\title{
Transnational Corporations' Outward Expression of Inward Self-Constitution: The Enforcement of Human Rights by Apple, Inc.
}

\author{
LARRY CATÁ BACKER*
}

\begin{abstract}
Societal constitutionalism presents us with alternatives to state-centered constitutional theory. But this alternative does not so much displace as extend conventional constitutional theory as a set of static premises that structure the organization of legitimate governance units. Constitutional theory, in either its conventional or societal forms, engages in both a descriptive and a normative project-the former looking to the incarnation of an abstraction and the later to the development of a set of presumptions and principles through which this incarnation can be judged. Constitutional theory is conventionally applied to states-that is, to those manifestations of organized power constituted by a group of individuals, bounded by a territory, and evidenced by the institution of government. But today a certain measure of disaggregation has managed to manifest a constituting power. Globalization has opened holes in the walls that used to serve to police and protect states and their power authority. Societal aggregations can exist now between borders. Groups of individuals (and not just natural persons) incarnate abstractions of governance and then judge them in ways that are consonant with constitutional theory. These emerging realities have produced societal constitutionalism. But like conventional constitutionalism, societal constitutionalism seeks the comfort of equilibrium and stasis as the basic operating premises of
\end{abstract}

* W. Richard and Mary Eshelman Faculty Scholar \& Professor of Law, Professor of International Affairs, Pennsylvania State University. The author may be contacted at lcb911@gmail.com. The paper was first presented at the International conference, Societal Constitutionalism and Globalization, hosted by the Hague Institute for the Internationalization of Law and the International University College, Torino, Italy, May 18, 2012. My thanks to Gunther Teubner (Goethe Universität Frankfurt am Main) and Anna Beckers (Maastricht University) for organizing this excellent conference.

Indiana Journal of Global Legal Studies Vol. 20, Issue 2 (2013)

(C) Indiana University Maurer School of Law 
self-constituting governance systems. This paper considers societal constitutionalism in its dynamic element-as a system structures constant adjustment among the constituting elements of a governance unit (whether state, corporation, religion, etc.)-in three dimensional governance space. After an introduction, Section I engages in framework setting, focusing on the structures of societal constitutionalism within the logic of globalization. Section II provides an illustration of a societally constituted enterprise operating in three dimensional dynamic governance space. Section III then develops the more important characteristics of this new dynamic and permeable constitutional framework. The paper concludes where it started-suggesting the need to expand our understanding of constitutional theory to include communication among systems in a complex polycentric constituting universe.

\section{INTRODUCTION}

Constitutional theory was once, and not so long ago, ${ }^{1}$ the province of the state. ${ }^{2}$ Its construction was meant to solidify and protect the ideology of a world order grounded on the state as the supreme (or in Marxist Leninist theory the sole) ${ }^{3}$ construction of abstract social-political-economic societies. The state stood not merely as the sole self-constituting community, but also, like the God of the Old Testament, ${ }^{4}$ produced an eco-system within a world populated by distinct and well-ordered subordinate enterprises that defined the

1. See Westel W. Willoughby, The Fundamental Concepts of Public LaW 30 (1924).

2. See generally J.P. Nettl, The State as a Conceptual Variable, in 1 THE STATE: CRITICAL CONCEPTS 9 (John A. Hall ed., Routledge 1994) (1968) (discussing how the state's role in constitutional design and the social sciences has declined over the past fifty years).

3. One must make a distinction between classical Marxist theory, which posited the withering away of the state but in which the theory of the state remain ambiguous at best. See Clyde Barrow, The Marx Problem in Marxian State Theory, 64(1) ScIENCE AND SOCIETY 87.118 (2000) (with Leninism and post Leninist theory); THE HISTORICAL EXPERIENCE OF THE DICTATORSHIP OF THE PROLETARIAT (1959), available at http://www.marx2mao.com/PDFs/HEDP56.pdf. Cf. VLADIMIR LENIN, THE STATE AND REVOLUTION, COLLECTED WORKS, VOLUME 25 381-492, available at http://www.marxists. org/archive/lenin/works/1917/staterev/ (especially The "Withering Away" of the State, and Violent Revolution).

4. See Genesis 1:1. 
international order, ${ }^{5}$ but also the private ecologies of the modern nongovernmental organization ${ }^{6}$ and the economic enterprise. ${ }^{7}$

But globalization, like the apple well digested by Adam and Eve, ${ }^{8}$ has expelled both constitution and constituting elements from the state of the Garden of Eden. ${ }^{9}$ There has been scholarly movement away from the state and even public international organization paradigms, ${ }^{10}$ to include private actors. ${ }^{11}$ The result has been the production of a mass of self-constituting and constituted societies, ${ }^{12}$ which exist in vertically and horizontally vectored arrangements of simultaneously governing, functionally differentiated ${ }^{13}$ governance organs. ${ }^{14}$ It has also produced a movement to advance another singular political project-the

5. See José E. Alvarez, International ORganizations as LAW-Makers (2006) (providing a description of these enterprises).

6. See generally Bob Reinalda \& Bertjan Verbeek, Theorizing Power Relations Between NGOs, Intergovernmental Organizations, and States, in NON-STATE ACTORS IN INTERNATIONAL RELATIONS 145 (Bas Arts et al. eds., 2001) (assessing the influence of nongovernmental organizations on international and transnational politics, as well as the importance of nonstate actors).

7. See generally Larry Catá Backer, Introduction to HARMONIZING LAW IN AN ERA OF Globalization: Convergence, Divergence, AND Resistance (Larry Catá Backer ed., 2007).

8. See Genesis 3:6.

9. See, e.g., Gunther Teubner, Societal Constitutionalism: Alternatives to State-Centred Constitutional Theory?, in TRANSNATIONAL GOVERNANCE AND CONSTITUTIONALISM 3 (Christian Joerges et al. eds., 2004) (discussing the effects of globalization on the governance of international regulations like the Internet).

10. See, e.g., Layna Mosley, Private Governance for the Public Good?: Exploring Private Sector Participation in Global Financial Regulation, in POWER, INTERDEPENDENCE, AND Nonstate ACTORS IN WORLd Politics 126 (Helen V. Milner \& Andrew Moravcsik eds., 2009) (discussing globalization effects on international markets and the roles played by private actors).

11. For an early and influential call to this effort, see generally ROBERT O. KEOHANE \& JosePh S. Nye, Power AND INTERDEPEndence (3d ed., Longman 2001) (1977). See also Peter R. BAEHR, NON-GovernmEnTal Human Rights Organizations IN INTERnational RELATIONS (2009).

12. I avoid the term "communities" because of its close connection with the work of another century and another sensibility. See, e.g., FERDINAND TöNNIES, COMMUNITY AND CIVIL SoCIETY (Jose Harris ed., Margaret Hollis trans., Cambridge Univ. Press 2001) (1887).

13. See, e.g., Anders Esmark, The Functional Differentiation of Governance: Public Governance Beyond Hierarchy, Market and Networks, 87 PUB. ADMIN. 351 (2009) (exploring the relation between the historical constitution of modern society's governance traditions and the transformation of public governance).

14. See generally DAVID SCHNEIDERMAN, CONSTITUTIONALIZING ECONOMIC GLOBALIZATION: INVESTMENT RULES AND DEMOCRACY'S PROMISE 1-21 (2008). 
development of a single global government. ${ }^{15}$ But it has also suggested the basic condition of fragmentation and power decentering as the basic condition within which governance is constituted. ${ }^{16}$ And it has also produced movements that suggest that what appears to be a broadening of constitutionalism outward from the state is instead the development of a kinetic element to governance grounded in networks, ${ }^{17}$ or of institutions that now mediate between legal, political, and economic realms. ${ }^{18}$ That religion is not included merely suggests an additional topic for the future when its constituting power becomes harder to avoid. ${ }^{19}$ But most importantly, it has begun to interrogate the current limits of constitutional theory-moving analysis from a grounding in state to one in societal constitutionalism. ${ }^{20}$ But does this alternative extend rather than displace conventional constitutional theory as a set of static premises that structure the organization of legitimate governance units?

Constitutional theory is grounded in two principal objectives-the first is to incarnate an abstraction, and the second is to develop a set of presumptions and principles through which this incarnation can be

15. See Richard Falk \& ANdrew Strauss, A Global Parliament: Essays and ARTICLES 13-18 (2011); Alexander Wendt, Why a World State is Inevitable, 9 EUR. J. INT'L REL. 491, 491 (2003).

16. See Andreas Fischer-Lescano \& Gunther Teubner, Regime Collisions: The Vain Search for Legal Unity in the Fragmentation of Global Law, 25 MiCH. J. INT'L L. 999, 1017-1044 (2004).

17. See AnNe-Marie Slaughter, A New World ORDer (2004) (arguing that a new manner of global governance has emerged through the use of ad hoc or treaty-based security and financial networks); Lars Viellechner, The Network of Networks: Karl-Heinz Ladeur's Theory of Law and Globalization, 10 GERMAN L.J. 515, 517-18 (2009) (citing Karl-Heinz Ladeur, Globalization and the Conversion of Democracy to Polycentric Networks: Can Democracy Survive the End of the Nation State?, in PUblic Governance IN THE AGE OF GLOBALIZATION 89, 99, 113 (Karl-Heinz Ladeur ed., 2004)) ("[H]e rather recognizes an adequate pattern of social organization for a radically fragmented and globalized society in a 'network of networks' of heterarchical social relationships generating collective order as a secondary transsubjective effect of individual cooperation and coordination under conditions of uncertainty.").

18. See Moritz Renner, Occupy the System! Societal Constitutionalism and Transnational Corporate Accounting, 20 IND. J. GLOBAL LEGAL STUD. 941 (2013).

19. See Larry Catá Backer, Theocratic Constitutionalism: An Introduction to a New Legal Global Ordering, 16 IND. J. GLOBAL LEGAL STUD. 85, 99, 106 (2009).

20. See Gunther Teubner, Fragmented Foundations: Societal Constitutionalism Beyond the Nation State, in The Twilight of Constitutionalism 327, 328-29 (Petra Dobner \& Martin Loughlin eds., 2010) (" $[\mathrm{H}]$ ow is constitutional theory to respond to the challenges arising from these two major trends of privatisation and globalisation? This is what today's 'constitutional question' ought to be. Today's constitutionalism moves beyond the nation state. It does so in a double sense: constitutionalism moves into the transnational context and into the private sector."). 
judged. ${ }^{21}$ With respect to the first objective, constitutional theory can be understood as engaging in a descriptive project. This project, of course, is one that also evidences choices among characteristics deemed necessary to reify the idea of the constituent elements, the constituting acts, and the outlines of the object constituted. ${ }^{22}$ Michel Foucault, ${ }^{23}$ perhaps, understood this best, without understanding its application to constitutional theory, when he described the way in which mass society has itself been incarnated from out of the mass of statistics, measures, habits, affinities, and characteristics that serve as an aggregation of circumstantial evidence of the object identified, and thus identified, given "life" (reality). ${ }^{24}$ That is, abstractions like society and government are understood only by reference to the means by which their presence and effects are measured. The choice of what to measure, then, also becomes a choice about how to construct society, its premises, and characteristics. Gunther Teubner ${ }^{25}$ understood best the functional characteristics of the formerly functionally constrained notion of law. ${ }^{26}$ But the descriptive project of constitutional theory does not produce a singular incarnation (despite the often misleading assertions of advocates of one or another of the forms it has taken). As such, constitutional theory must also be grounded judgment, and thus the second objective.

With respect to this second objective, constitutional theory can be understood as engaging in a normative project-a project that speaks to fundamental values in the relationship of the entity to its members and to others, ${ }^{27}$ and to constrain politics. ${ }^{28}$ This is a project that is meant to

21. See Larry Catá Backer, From Constitution to Constitutionalism: A Global Framework for Legitimate Public Power Systems, 113 PENN ST. L. REV. 671 (2009).

22. See Kaarlo Tuori, The Failure of the EU's Constitutional Project: A Cultural Discrepancy, in CONSTITUTIONALISM: NEW CHALlENGES: EUROPEAN LAW FROM A NORDIC PERSPECTIVE 103, 109 (2008) ("In the political system, the constitution fulfills both an organizational and a legitimizing function. The organizational part ... defines the basic institutional structure of political power ... The constitution channels the legitimacy of the law into the political system.").

23. Michel Foucault (1926-1984) was a highly influential, though controversial, philosopher and social theorist well known for his work on the nature of governance and institutional power and control. For biographies, see DIDIER ERIBON, MicHEL FOUCAULT (Betsy Wing, trans., 1991); DAVID MACEY, THE LIVES OF MiCHEL FoUCAULT (1994).

24. Michel Foucault, Security, Territory, Population: lectures at the Collège DE FranCE 1977-1978, at 110 (Michel Senellart ed., Graham Burchell trans., Macmillan 2007) (2004).

25. Professor Gunther Teubner is a German legal scholar and sociologist, best known for his works within the field of Social Theory of Law.

26. See Gunther Teubner, "Global Bukowina": Legal Pluralism in the World Society, in Global LaW Without a STate 3, 3-5 (Gunther Teubner ed., 1997).

27. See Larry Catá Backer, God(s) Over Constitutions: International and Religious Transnational Constitutionalism in the 21st Century, 27 MISS. C. L. REv. 11 (2008). 
help distinguish among incarnations of institutional actors, ${ }^{29}$ as well as among those societal aggregations from which such constructions might arise. It thus is meant to tie constitution to the greater project of social normative construction. Constitutional theory speaks of these distinguishing values/premises in terms of democracy, human rights and dignity, sustainability, and the like. But again, even the construction of social normative structures occurs in the plural. So, constitutional theory must also account for the normative values that would be central to its normative project-developing a basis for judging the choice and use of normative values in the incarnation of a constituted social object. To this end, legitimacy becomes a central component of the normative project of constitutional theory, with the evaluation of the "guts" of the incarnated (constituted) being the great focus. Constitutional theory speaks of these distinguishing values/premises in terms of rule of law, process, accountability, participation, and the like. That discussion is as possible within nonstate governance units as it is within states. That is part of the urtext of societal constitutionalism, at once primal, seminal, or prototypical.

Constitutional theory, traditionally, has been applied to creations holding political power-that is, to those manifestations of organized power constituted by a group of individuals, bounded by a territory, and evidenced by the institution of government. ${ }^{30}$ Territory and power served as the boundaries from within which these incarnations of aggregated existence operated-whether in legitimate or illegitimate form. Power was understood to be plenary (and thus political) in the sense that it could extend to the management of the life, property, and liberty of individuals subject to its will. ${ }^{31}$ Such creations (national states) were autonomous and supreme within their territory. These territories would have to deal with other territories differently from the

28. Pedro Cruz Villalon, la formacíon del sistema Europeo de control de CONSTITUCIONALIDAD (1918-1939) (1987) (analyzing European constitutional experiences between the First and Second World Wars).

29. For example, constitutionalism's normative project has as an objective the creation of structures of taxonomies of governments by type and of ways to distinguish among them. See, e.g., Louis Henkin, A New Birth of Constitutionalism: Genetic Influences and Genetic Defects, in ConstituTIONALISM: IDENTITY, DifFERENCE AND LEgITIMACY Theoretical Perspectives 39 (Michel Rosenfeld, ed., 1994).

30. See Dieter Grimm, The Constitution in the Process of Denationalization, in CONSTITUTIONALISM: NEW CHALLENGES: EUROPEAN LAW FROM A NORDIC PERSPECTIVE, supra note 22, at 71, 81 ("From a historical perspective, the constitution presupposes the state as a form of political community.').

31. Cf. U.S. CONST. amend. XIV (the state's power to deprive individuals of their life, liberty, or property is limited only by concepts of due process). 
way they interacted with persons or entities within their territory. These states developed methods of communication with each other that, in its day, were understood by the monikers international law and relations. For some, those monikers remain the unique boundary posts of constitutional discourse, within which all else ought to be subsumed. ${ }^{32}$ The extension of traditional constitutional theory is sometimes structured within notions of cosmopolitanism-though ones in which like systems are always matched with like systems. ${ }^{33}$

In contrast, societal constitutionalism is grounded in the insight that today a certain measure of disaggregation has managed to manifest a constituting power, manifestations that are understood to exist within a constitutional framework. ${ }^{34}$ Globalization has opened holes in the walls that used to police and protect states and their power authority. Societal aggregations can exist now between borders. Groups of individuals (and not just natural persons) incarnate abstractions of governance and then judge them in ways that are consonant with constitutional theory. The territorial demarcations of these "states" are functional, and their power is bounded by the logic of the purpose of their existence. Yet, even without territory or the full panoply of political power, they can manifest an autonomous self-awareness and functionality that recalls the constitutional structures of states. ${ }^{35}$ Though not states, they exist as constitutional entities all the same. These entities are developing methods of communicating with each other and with states through a variety of mechanisms-only some of which are grounded in the forms and content of traditional structures of law. ${ }^{36}$

The absence of territory also makes demarcation more nebulous. These societal constitutional organisms exist without the orderly arrangement of states (and the entities they have spawned within the international sphere). More complicated still, these societally constituted organisms exist alongside, within, between, and among states. Polycetricity, thus, marks the new world order for constitutional

32. Id. at 80 .

33. See Vlad F. Perju, Cosmopolitanism and Constitutional Self-Government, 8 INT'L J. CONST. L. 326 (2010).

34. See, e.g., DAVID ScIUlli, ThEORY OF SOCIETAL CONSTITUTIONALISM: FoundationS OF A NON-MARXIST CRITICAL THEORY (1992).

35. See, e.g., GUNTER TEUBNER, CONSTITUTIONAL FragmentS: SOCIETAL CONSTTTUTIONALISM AND Globalization (2012). Cf. Richard Albert, The Cult of Constitutionalism, 39 FLA. ST. L. REV. 373 (2012).

36. See Larry Catá Backer, Governance Without Government: An Overview, in BEYOND TERritoriality: Transnational LEgal AUTHORITY IN AN AGE OF GLOBALIZATION 87 (Günther Handl et al. eds., 2012). 
organisms. ${ }^{37}$ This sometimes produces a tendency to develop meta-management approaches. ${ }^{38}$ In a world infused with incarnated constitutional beings existing polycentrically in a virtual three-dimensional bowl filled with the stuff of constitutional possibility, the bowl itself will not be visible and the constitutional possibilities within it will resist management of any effective kind. ${ }^{39}$

Like conventional constitutionalism, societal constitutionalism seeks the comfort of equilibrium and stasis as the basic operating premises of self-constituting governance systems. This paper considers societal constitutionalism in its dynamic element-as a system structures constant adjustment among the constituting elements of a governance unit (whether state, corporation, religion, etc.). Building on Gunther Teubner's insights of communicative hypercycle and ultra cycle, ${ }^{40}$ it introduces the concept of dynamic societal constitutionalism. The dynamic element of societal constitutionalism posits disequilibrium as the equilibrium state for societally constituted systems. Equilibrium is aberrational, though the coherence of the institutions within which dynamic interaction happens is itself relatively stable. The self-referencing communication at the core of dynamic institutional coherence creates conditions for a constant state of dynamic flux as stakeholders and the governance apparatus adjust behavior to maximize welfare. Systemic integrity is grounded in the constitutional norms within which a governance unit is organized, but even these are connected to frameworks of common standards shared by governance unit stakeholders. Dynamic societal constitutionalism suggests that just

37. Larry Catá Backer, From Institutional Misalignments to Socially Sustainable Governance: The Guiding Principles for the Implementation of the United Nations' 'Protect, Respect and Remedy" and the Construction of Inter-Systemic Global Governance, 25 PAC. MCGEORGE GLOBAL BUS. \& DEV. L.J. 69 (2012) (analyzing an example of the framework of the U.N. Guiding Principles on Business and Human Rights). See also Inger-Johanne Sand, Polycontextuality as an Alternative to Constitutionalism, in TRANSNATIONAL GovERNANCE AND CONSTTTUTIONALISM, supra note 9 , at 41.

38. See, e.g., Paul Schiff Berman, Jurisgenerative Constitutionalism: Procedural Principles for Managing Global Legal Pluralism, 20 IND. J. Global LEGAL STUD. 665 (2013).

39. For a recent, quite thought-provoking effort at both seeing the bowl and suggesting the possibility of management, see Christian Joerges, Conflicts-Law Constitutionalism: Ambitions and Problems (ZENTRA Working Papers in Transnational Studies, No. 10/2012), available at http://papers.ssrn.com/sol3/papers.cfm?abstract_id=2182092 ("There are many ways to avoid, to suspend or to manage conflict constellations. If we identify responses which 'deserve recognition' because they are based upon considerations of jusitce, we can adhere to the notion of law." Id. at 19).

40. See Gunther Teubner, Self-Constitutionalizing TNCs? On The Linkage Of "Private" And "Public" Corporate Codes Of Conduct, 18 IND. J. GLOBal Legal STUD. 617, 632-35 (2011). 
as the absence of territory as a basis for constituting a governance space has made regulatory frameworks more fluid and permeable, it also reduces the importance of stability as a necessary ingredient for institutional coherence and societal stability.

After an introduction, Section I engages in framework setting, a consideration that necessarily structures societies and their constitution from a spatially static and inward-looking perspective. That investigation is divided into two parts: first, the parameters for the ordering system of states and nonstate actors, and second, a brief consideration of the constitution of corporate actors within this framework. The specific object of the second part is the multinational corporation, an exemplar of a self-constituted enterprise at the center of an autonomously constituted governance system, with its focus on Apple, Inc.

Section II provides an illustration of a societally constituted enterprise operating in three dimensional dynamic governance space; it seeks to describe the dynamics of societal constitution within dynamic polycentric structures of effect and communication. The focus is Apple, Inc.; the context is the enforcement of international human rights norms through the governance activities of Apple Inc. and its supply chain, specifically the spaces where systems converge, harmonize, and collide. The object is to consider a societally constituted governance unit operating in three-dimensional space that is in constant motion, but within which the entity remains stable. Like the state within a dynamic international system, Apple Inc. assumes a central place around which, and through its operations, produces collisions between its societal constitution, its formal place within the constitution of states, and its functional role within the constitution of global economic society within this multidimensional governance space, and the permeability of its operations and structural coupling while retaining a stable internal governance framework. This suggests a dynamic element of societal constitutionalism that tends to be overlooked in standard accounts that posit a static governance universe, even if a layered one.

Section III then develops the more important characteristics of this new dynamic and permeable constitutional framework. If societies can be understood as subject to certain principles for their inward constitution, to what extent might there be principles that affect the outward expression of inward self-constitution? That consideration requires both an examination of the way in which societally constituted entities may be felt and seen by outsiders and also the way that expressive communication can have inward-affecting consequences. For 
that purpose, Gunther Teubner's notions of addiction ${ }^{41}$ and $\operatorname{chaos}^{42}$ and Hans Lindahl's notions of spatiality and communication ${ }^{43}$ serve as a starting point. Proceeding from the intuitions derived from Section II, it deepens the insights of a dynamic element within societal constitutionalism. Thought of merely as a static structuring-conventional analysis may fail to capture the critical importance of structural coupling in defining both the autonomy of systems and their communicative intimacies among systems in a complex polycentric constituting universe. Building on networks and irritants in the governance space, this section uses a recent episode in the operations of Apple, Inc. as an example of the behavior of systems within a governance space characterized by fragmentation, fluidity, polycentricity, and permeability. ${ }^{44}$ The example may illustrate a possible difference between public and private constitutional spaces. Public law-based constitutionalism, positing stasis and equilibrium as the normal state, ${ }^{45}$ treats conditions of disequilibrium, a constant state of change or revolution, as aberrational. ${ }^{46}$ Equilibrium is a sign of

41. See Gunther Teubner, Legal Irritants: Good Faith in British Law or How Unifying Law Ends Up in New Divergences, in The EuRopeanisation of LaW: The Legal EFFECTS of EUROPEAN INTEGRATION 243 (Francis G. Snyder ed., 2000).

42. Gunther Teubner, A Constitutional Moment? The Logistics of 'Hit the Bottom,' in AFter the CATASTROPHE: ECONOMY, LAW AND Politics IN TIMES of CRISIS (Poul F. Kjaer \& Gunther Teubner eds., 2010).

43. See Hans Lindahl, The Boundaries of Legal Orders in a Postnational Setting: Conceptual, Normative and Institutional Issues, in THE LAW OF THE FUTURE AND THE FUTURE OF LAW 355 (Sam Muller et al. eds., 2011), available at http://www.fichl.org/file admin/fichl/documents/FICHL_11_Web.pdf.

44. See Larry Catá Backer, The Structural Characteristics of Global Law for the 21st Century: Fracture, Fluidity, Permeability, and Polycentricity, 17 TILBURG L. REv. 177 (2012).

45. "[I]ndeed, it has always seemed to me that a primary purpose of constitutionalism is precisely to entrench certain principles and structures against change, particular change driven by popular pressure." Ernest A. Young, Popular Constitutionalism and the Underenforcement Problem: The Case of National Healthcare Law, 75 LAW \& CONTEMP. PROBS. 157, 185 (2012). See also Russell Muirhead \& Nancy L. Rosenblum, The Partisan Connection, 3 CAL. L. REv. CIRCUIT 99 (2012) ("The purpose of eighteenth-century constitutionalism was twofold, and each purpose was in tension with the other; on one hand, to facilitate popular power and empower 'the common, recognizable interests of ordinary people, and nothing more.' On the other, to constrain popular power to ensure that majorities could not overwhelm the permanent and aggregate interests of the community," id. citing in part Philip Pettit, Democracy, Electoral and Contestatory, in 42 NOMOS: DESIGNING DEMOCRATIC INSTITUTIONS 134 (Ian Shapiro \& Steven Macedo eds., 2000)); The FederalisT No. 10 (James Madison) (Project Gutenberg Etext ed. 1992), available at $\mathrm{http}: / /$ thomas.loc.gov/home/histdox/fedpaper.txt.).

46. It is easiest to contrast the equilibrium and stability of constitutionalism with notions of permanent revolution best described by Leon Trotsky. Leon Trotsky, The Permanent Revolution (1931), available at http://www.marxists.org/archive/trotsky/1931/ 
system integrity and success. ${ }^{47}$ Dynamic societal constitutionalism produces a more complex model of the well-known but utterly two dimensional "living constitution" 48 through which mass preferences are in constant dialogue with common norms to produce stable governance under conditions of constant change that may or may not be dependent on the state or any specific judicial apparatus. ${ }^{49}$

The paper concludes where it started-in constitutional theory. It suggests the need to expand our understanding of constitutional theory beyond incarnation and judgment, to include communication among systems in a complex polycentric constituting universe. It suggests the dynamic consequences of this emerging societal framework of hierarchical power arrangements and horizontal effects for constitutional theory among this amalgam of states and other societally constituted organisms.

tpr/pr-index.htm (last visited Aug. 13, 2013) ("The permanent revolution, in the sense which Marx attached to this concept, means a revolution which makes no compromise with any single form of class rule, which does not stop at the democratic stage, which goes over to socialist measures and to war against reaction from without: that is, a revolution whose every successive stage is rooted in the preceding one and which can end only in the complete liquidation of class society."). These might also have been in evidence during the Chinese Cultural Revolution. See Mo Jihong, The Constitutional Law of the People's Republic of China and Its Development, 23 COLUM. J. ASIAN L. 137 ("The 1975 and 1978 Constitutions were influenced by the extreme leftist sentiments of the Cultural Revolution, which promoted a theory of continuing revolution under proletarian dictatorship, inconsistent with the basic principles of modern constitutionalism." Id. at 139). Both have been rejected by notions of stability inherent in Western and Chinese constitutionalism, through policies of "general welfare" and "harmonious society."

47. See, e.g., William H. Rehnquist, The Notion of a Living Constitution, 54 TEx. L. REV. 693, 704-06 (1976) (on the judicial role in promoting constitutional stability).

48. Two-dimensional in the sense that communication is abstracted through the institutions of the state separated by function and each constructed to represent an aggregate understanding of popular sentiment. See, e.g., William C. Heffernan, Constitutional Historicism: An Examination of the Eighth Amendment Evolving Standards of Decency Test, 54 AM. U. L. REv. 1355 (2005) ('Advocates of the concept of a 'living constitution,' for example, reason in terms of a body of constantly remade constitutional doctrine-surely an unhelpful approach given the continuity and stability characteristic of most areas of constitutional law." Id. at 1363); see also Paul Brest, The Intentions of the Adopters Are in the Eyes of the Beholder, in THE BILL OF RIGHTS: ORIGINAL MEANING AND CURRENT UNDERSTANDING 17-18 (Eugene W. Hickok, Jr. ed., 1990) (focusing on stability and flexibility).

49. See, e.g., Gunther Teubner, Societal Constitutionalism: Alternatives to State-Centered Constitutional Theory?, in TRANSNATIONAL GOVERNANCE AND CONSTITUTIONALISM 3, 26-27 (Christian Joerges, Inge-Johanne Sand \& Gunther Teubner eds., 2004). For a good discussion of the germinal literature from which these ideas arise, see David Nelken, Eugen Ehrlich, Living Law, and Plural Legalities, 9 THEORETTCAL INQUTRIES IN LAW 443 (2008). 


\section{CONSTITUTING A SOLAR SYSTEM OF ACTORS}

No discussion of the ordering systems of self-constituting societies is possible without a sense of the normative framework within which this self-constituting and the communication between these self-constituting organs exist. ${ }^{50}$ This section briefly suggests the contours within which societies constitute themselves and the way in which their legitimacy is judged. It then describes the normative framework within which human rights are recognized and governed. Finally, it identifies the various constitutional societies that together map the polycentric system within which human rights specific governance exists.

\section{A. An Ordering System of States and Nonstate Actors: The Starting Point for State and Societal Constitutionalism}

Constitutionalism itself, whether in the form of the narrow state-based constitutionalism or the broader concepts of societal constitutionalism, remains a contested idea, even when connected entirely to the state and the political, ${ }^{51}$ and especially when it is applied autonomously to nonstate actors. ${ }^{52}$ The state, itself, as the framework into which constitutionalism is projected, has been unmasked as contingent and fragile, sometimes irrelevant. ${ }^{53}$ Constitutionalism's

50. "The thesis is: the emergence of a multiplicity of civil constitutions. The constitution of world society does not come about exclusively in the representative institutions of international politics, nor can it take place in a unitary global constitution which overlies all areas of society, but, instead, emerges incrementally in the constitutionalisation of a multiplicity of autonomous sub-systems of world society." Teubner, supra note 9 , at 8 .

51. Constitutionalism in this context is discussed in Backer, supra note 21. Its arrested development within state ideology constructs is discussed in Mattias Kumm, The Cosmopolitan Turn in Constitutionalism: An Integrated Conception of Public Law, 20 IND. J. GLOBAL LEGAL STUD. 605 (2013). See also Reza Dibadj, Panglossian Transnationalism, 44 STAN. J. INT'L L. 253 (2008).

52. Ulrich K. Preuss, Disconnecting Constitutions from Statehood: Is Global Constitutionalism a Viable Concept, in THE TWILIGHT OF CONSTITUTIONALISM?, supra note 20, at 23,43 .

53. See generally Peter T. Leeson \& Claudia R. Williamson, Anarchy and Development: An Application of the Theory of Second Best, 2 LAW \& DEV. REV. 75 (2009) ("[C]onditional on failure to satisfy a key institutional condition required for ideal political governance-constrained politics-citizens' welfare is maximized by departing from the other conditions required for this form of governance: state-supplied law and courts, state-supplied police, and state-supplied public goods."); Ken Menkhaus, Governance Without Government in Somalia: Spoilers, State Building, and the Politics of Coping, 31 INT'L SECURITY 74 (2007) (explaining that Somalia has been without a functional central government since 1991); Larry Catá Backer, Of Somali Pirates, Global Corporations and the State: Governance Without Government, Government Without a State and Military Power, LAW AT THE END OF THE DAY (June 28, 2009, 5:04 PM), 
connection to law has also spawned substantial debate. ${ }^{54}$ The debate intensifies when the logic and ideology of state-centered law is used to attempt to domesticate nonlaw governance systems. ${ }^{55}$ More importantly, its application to nonstate actors generates a substantial amount of controversy as well. ${ }^{56}$ Even when there is a concession to the idea that constitutionalism itself is not inherently bundled with the construction of political states, there is a concern that its own self constitution may be impeded in part by the state from which it arose or the market within the orbit of which it may disintegrate. ${ }^{57}$ Moreover, the basic issue of constitutionalism-defining the borders of self-constructed constitutionalist orders-remains acute. ${ }^{58}$ Deterritorialization may also both strengthen ${ }^{59}$ and weaken ${ }^{60}$ national political constitutionalism.

http://cbackerblog.blogspot.com/2009/06/of-somali-pirates-global-corporations.html (viewing the recent ransoming of a ship by Somali pirates as an example of the overlap of private and public regimes, nonstate governments, traditional states, and nonstate entities as regulators).

54. See, e.g., Jaye Ellis, Constitutionalization of Non-Governmental Certification Programs, 20 IND. J. GloBAL LEGAL STUD. 1035 (2013); Anna di Robilant, Genealogies of Soft Law, 54 AM. J. COMP. L. 499 (2006); Craig Scott, Transnational Law' as Proto-Concept: Three Conceptions, 10 GERMAN L.J. 877 (2009).

55. E.g., Ming-Sung Kuo, Taming Governance with Legality? Critical Reflections Upon Global Administrative Law as Small-C Global Constitutionalism, 44 N.Y.U. J. INT'L L. \& POL. 55 (2011).

56. See, e.g., Christopher Thornhill, A Sociology of Constituent Power: The Political Code of Transnational Societal Constitutions, 20 IND. J. GLOBAL LEGAL STUD. 551 (2013) ("Transnational societal constitutions, it is claimed, in fact remain instruments, albeit at a high level of dispersal, for the societal allocation and distribution of power. Furthermore, the paper argues that transnational societal constitutions reproduce themselves through an intensification of the inclusionary and power-producing functions of rights already established in national-state constitutions.").

57. See Emilios Christodoulidis, On the Politics of Societal Constitutionalism, 20 IND. J. GLOBAL LEGAL STUD. 629 (2013) (describing how distance from the state may undercut its grounding and the power of the market may capture it, producing mutual thwarting rather than engagement).

58. See Saskia Sassen, Visible Formalizations and Formally Invisible Facticities, 20 IND. J. GLOBAL LEGAL STUD. 3 (2013). Indeed, yet in Africa, internationalization and de-territorialization might appear to aid the process of strengthening the state. See also Charles Manga Fombad, Internationalization of Constitutional Law and Constitutionalism in Africa, 60 AM. J. COMP. L. 439, 463-71 (2012).

59. See, e.g., Hans Lindahl, We and Cyberlaw: The Spatial Unity of Constitutional Orders, 20 IND. J. GLOBAL LEGAL STUD. 697 (2013) ("[T] c claim that spatial boundaries are no longer a constituent feature of post-state legal orders is effectively to hold that the boundaries of the territorial state, or of earlier spatially bounded communities, exhaust the manner in which legal orders close themselves into an inside vis-à-vis an outside.").

60. See, e.g., Anne Peters, Compensatory Constitutionalism: The Function and Potential of Fundamental International Norms and Structures, 19 LEIDEN J. INT'L L. 579, 580 (2006) (explaining how regionalization, global networks, and de-territorialization are contributing to de-constitutionalization on the domestic level). 
Indeed, the connection between constitutions and the state may serve to reduce the relevance constitutionalism itself as the normative or structuring vehicle for the organization of governance units institutionalized into something that resembles but is not government. ${ }^{61}$

Constitutionalism, whether or not detached from the state, ${ }^{62}$ frames a discussion about the organization of power. When individuals aggregate something-power, capital, goods, labor, or anything else of mutual benefit-those individuals, and others who deal with this aggregation, face a fundamental difficulty in two parts. The first part involves reification; a constituted society must understand itself to exist and others must understand the nature of this existence in the same way. ${ }^{63}$ For example, the corporation is manifested through its financial statements (rather than, for example, through reports about its impacts on the social, economic, or environmental impacts of its activities on others), which produces a very specific way of manifesting corporations that is in line with normative assumptions about its "nature."64 Likewise, the state is manifested to foreigners by its borders and to its inhabitants by its police powers, each shaped by the assumptions about the "nature" of the state. This implicates two issues: one involving the construction of an autonomous consciousness of this aggregation (its government), and the other involving the acts and forms required to make the aggregation "seen and felt" by others (people who are strangers to the constitution of an aggregation). ${ }^{65}$ Internal and external recognition are the first markers of the constituting entity. Form and function in the construction of the felt realities of these aggregations

61. See Riccardo Prandini, The Future of Societal Constitutionalism in the Age of Acceleration, 20 IND. J. GLOBAL LEGAL STUD. 731 (2013) (challenging the state constitutionalist concepts that constitutions are legitimized through consent of the state's subjects, that constitutions are structures for managing and constraining power, and that constitutions institutionalize a permanent relationship between governance apparatus and its subjects).

62. Cf. Neil Walker, The Idea of Constitutional Pluralism, 65 MoD. L. REv. 317 (2002).

63. See, e.g., Roman Guski, Autonomy as Sovereignty: On Teubner's Constitutionalization of Transnational Function Regimes, 11(2) INT. J. CONST. L. 523-36 (2013). See generally GUNTHER TEUBNER, LAW AS AN AUTOPOIETIC SYSTEM (Zenon Bankowski ed., Anne Bankowska \& Ruth Adler trans., 1993); Gunther Teubner, Hypercycle in Law and Organization: The Relationship Between Self-Observation, Self-Constitution and Autopoiesis, in EUROPEAN YEARBOOK IN THE SoCIOLOGY OF LAW 43 (Alberto Febrajjo ed., 1988).

64. These assumptions serve as the foundation for corporate disclosure under the U.S. federal securities laws, see, for example, Reg. S-X, 17 C.F.R. Part 210, and are also the foundation of investor views of the corporation-that is, the sum of its financial characteristics.

65. There is a parallel here to the notion of recognition of states in international law. See Montevideo Convention on Rights and Duties of States art. 1, Dec. 26, 1933, 165 L.N.T.S. 19 (listing requirements for recognizing personhood with its basis in acquiring all the characteristics that the community of like constituted organizations recognize as essential for self constitution). 
remain a lively topic of debate between "institutionalists" concerned with the organization of the apparatus of self-constitution, ${ }^{66}$ those worried about inclusion in the process of self-constitution, ${ }^{67}$ and the "anarchists" concerned with the dismantling of power-hierarchy systems in favor of polycentric and horizontally-aligned inter-connected systems. ${ }^{68}$

The second part of aggregation by individuals involves normative values that implicate system legitimacy. Legitimacy, like reification, can also be understood in two aspects. The first aspect involves the adoption of processes that remove the operation of governance organs from the control of individuals. That is, the organization is operated to maximize the welfare of the organization (or of its members understood as all members) in a manner that avoids arbitrary decision-making or operation for the benefit of some individuals rather than for the community as a whole. This is sometimes understood under notions of Rechtsstaat, or process rule of law. ${ }^{69}$ It is criticized as a move toward authoritarian managerialism. ${ }^{70}$ The second aspect involves the values that are meant to be advanced under legitimate process systems. These Sozialstaat notions have become central to the ideals of legitimacy in the construction of aggregations that have become self-constituting actors. ${ }^{71}$ For political organs, like states, those notions are the product of the shared values of the national community, but they may also be tempered by limiting norms and values of the international community, memorialized in the pronouncements of international organizations and, more narrowly, by international law. ${ }^{72}$ This latter project can be

66. Institutionalists cross the political spectrum from Stalinists to free market advocates. See Larry Catá Backer, Economic Globalization Ascendant and the Crisis of the State: Four Perspectives on the Emerging Ideology of the State in the New Global Order, 17 BERKELEY LA RAZA L.J. 141 (2006).

67. See, e.g., Gavin W. Anderson, Societal Constitutionalism, Social Movements, and Constitutionalism from Below, 20 IND. J. GLOBAL LEGAL STUD. 881 (2013).

68. For a modern articulation of this debate in the constitutionalist setting, see Saki Bailey \& Ugo Mattei, Social Movements as Constituent Power: The Italian Struggle for the Commons, 20 IND. J. GLOBAL Legal STUD. 965 (2013). See generally the essays in THE ANARCHIST COLLECTIVES: WORKERS' SELF-MANAGEMENT IN THE SPANISH REVOLUTION 1936-1939 (Sam Dolgoff ed., 1990).

69. Rule of law is a vast topic beyond the scope of this essay. For a discussion of the rule of law in globalization, for example, see SCHNEIDERMAN, supra note 14, at 205-22; ASIAN DIScouRses of RULE OF LAW (Randall Peerenboom ed., 2004).

70. See Joerges, supra note 39.

71. On substantive rule of law, see, e.g., Randall. PEerenboom, China's Long March TOWARD RULE OF LAW 2-55 (2002) (exploring substantive constitutionalism through the prism of rule of law concepts).

72. See Backer, supra note 27, at 17; Cheryl Saunders, Towards a Global Constitutional Gene Pool, 4 Nat'L TaIWan U. L. Rev. 1, 18 (2009). 
problematic and has been criticized as a Western project of normative neo-colonialism. ${ }^{73}$ For nonstate actors, the values framework may be related specifically to the objectives that brought the community together. ${ }^{74}$

Organization and legitimacy, then, mark the constitutional project. And it is a project bounded by text--however broadly constructed..$^{75}$ It is hardly enough to merely treat constitutionalism as an internal act; it has an external aspect as well. Constitutionalism requires the formation of an autonomous organization by the members of the enterprise (state, corporation, religious body) that is recognized as such by other communities that will have to deal with this entity. ${ }^{76}$

Constitutionalism as weltanschauung contains within it its own ontology (a descriptive model of legitimate constitutions), explanations (the purpose of constitutions), objectives (the ultimate aim of constitutions), values (constitutional ethics), methodology (a theory of action or means of obtaining the goals of constitutions), epistemology (a theory of knowledge, of figuring out true and false constitutions), and its own etiology (an account of the building blocks of constitutions). ${ }^{77}$

Critical to this complex set of organizing presumptions for societal constitutions is the fundamental premise of consent. Societally constituted organizations are grounded in the consensual act of a group that comes together for the purposes all members agree upon and that then institutionalizes that aggregation so that the society created becomes something that is autonomous of its members and is recognized

73. Yadh Ben Achour, L'Internationalisation du Droit Constitutionnel [Internationalization of Constitutional Law], in 16 L'INTERNATIONALISATION DU DROIT CONSTITUTIONNEL: RECUEIL DES COURS [INTERNATIONALIZATION OF CONSTITUTIONAL LAW: COLLECTION OF COURSE] 22 (2007) (recognizing the neo-colonialist character but arguing that it appears in more palatable form); Backer, supra note 27, at 16-17.

74. See Larry Catá Backer, Multinational Corporations as Objects and Sources of Transnational Regulation, 14 ILSA J. INT'L \& COMP. L. 499 (2008).

75. Cf. Ino Augsberg, Reading Law: On Law as a Textual Phenomenon, 22 L. \& LITERATURE 369 (2010) (describing systems themselves as a form of textuality).

76. See generally Backer, supra note 21. Notions of incarnation as a basis for corporate autonomy have been suggested. See Saru M. Matambanadzo, The Body, Incorporated, 87 TUL. L. REv. 457 (2013). These ideas parallel those long advanced in public law. See, e.g., ERnst H. Kantorowicz, The King's Two Bodies: A StUdy IN Medieval Political THEOLOGY (1957) (on nonstate collective personality, see id. at 273-313).

77. Backer, supra note 21 , at 720 . 
as such by those with whom it must deal. ${ }^{78}$ Beyond this simple constituting condition lies much of the methodological and substantive detail of foundational organization understood as constituting an autonomous body. ${ }^{79}$

I have earlier suggested a topology for this fundamental understanding of the constitutionalist project for states. ${ }^{80} \mathrm{I}$ have also suggested its utility in the analysis of self-constituting nongovernmental groups-principally nonstate corporate actors.81 Once one assumes away the fundamental ordering principals of states-that they exist as unique organizations of power fused from the union of people and territory from which all other organizations are derived, or if not derived, that can govern only through deployment of measures that are less legitimate or authoritative (less than law)-the possibilities of ordering the constitutions of organizations without a state become clearer. The organizational element of a nonstate constitution centers on four principal characteristics: (1) scope of authority, (2) institutional autonomy, (3) regulatory authority, and (4) effectiveness of power to settle disputes. ${ }^{82}$ These have a constitutional element-the organizing principles that give the regulatory community form and set its organizational boundaries. ${ }^{83}$ These boundaries include the constitution of a government apparatus and the rules for the operation of the governance power vested in this organization. They also have substantive and process elements, including the rules, laws, and other

78. This is what I have previously argued as the essence of the substantive or constitutional component of transnational law. See Larry Catá Backer, Principles of Transnational Law: The Foundations of an Emerging Field, Law at the End of the Day, Mar. 9, 2007, available at http://lcbackerblog.blogspot.com/2007/03/principles-of-transnati onal-law.html. But others see in this a methodological component that then creates a space for regulatory institutionalization within networks of governance systems. See Gralf-Peter Caldiess \& Peer Zumbansen, Rough Consensus and Running Code: A Theory of Transnational Private LaW (2010); Peer Zumbansen, Transnational Law, Evolving (Dec. 15, 2011), Osgoode CLPE Research Paper No. 27/2011 (revising a prior version produced for the Elgar Encyclopedia of Comparative Law (Jan Smits, ed., 2006)).

79. See Peer Zumbansen, Transnational Law, Evolving (Osgoode Hall Law Sch. Comparative Research in Law \& Political Econ., Research Paper No. 27/2011), available at http://ssrn.com/abstract=1975403.

80. Backer, supra note 21 , at 720 .

81. See generally Larry Catá Backer, Transnational Corporate Constitutionalism: The Emergence of a Constitutional Order for Economic Enterprises, SoC. SCI. RES. NETWORK (April 10, 2012), available at http://papers.ssrn.com/sol3/papers.cfm?abstract_id=2038081 (exploring the emerging principles of transnational constitutionalism as a basis for the organization and integration of economic enterprises).

82. See Larry Catá Backer, Principles of Transnational Law: The Foundations of an Emerging Field, Law at the End of the Day (Mar. 9, 2007), available at http://lcbackerblog. blogspot.com/2007/03/principles-of-transnational-law.html.

83. Id. 
norms that are produced or administered by the community and the process rules through which they are applied, enforced, constructed, and interpreted. ${ }^{84}$

The normative elements are grounded in legitimacy, and touch on those structures that make it possible both to "see" the self-constituting enterprise and to treat it, both inside and outside, as a "thing" legitimately apart from its stakeholders. ${ }^{85}$ These societally constituted enterprises, then, are structured as a system of taxonomy and legitimation that is grounded in a set of normative assumptions about the purpose of government and its connection to governance. One can unpack this system in the form of five core elements: Constitutionalism can be understood (1) as a system of classification; (2) the core object of which is to define the characteristics of constitutions (those documents that organize governance power within an institutional apparatus); (3) to be used to determine the legitimacy of the constitutional system as conceived or as implemented; (4) based on rule of law as the fundamental postulate of government (that government be established and operated in a way that limits the ability of individuals to use government power for personal welfare maximizing ends); and (5) grounded on a metric of substantive values derived from a source beyond the control of any individual. ${ }^{86}$

This framework is applicable to all self-constituting governance systems in which the organization of governance is overseen by an institutional apparatus of some kind. But the resulting fracture and decentering of the state has been criticized as well. ${ }^{87}$

Constitutionalism of this sort provides a point of convergence between public and private governance systems. It offers both norm and technique in the constitution of governance that is not limited by the conceptual blinders of a state system that, through its imposition of hierarchy of legitimacy, reserves only to the state the power of self constitution and regulatory

84. See Gralf-Peter Calliess \& Peer Zumbansen, Rough Consensus and Running Code: A Theory of Transnational Private Law (2010) (exploring the shifting institutional and normative landscape of legal norm-creation).

85. See Backer, supra note 82.

86. Backer, supra note 21 , at 679 .

87. See generally Petra Dobner, On The Constitutionability of Global Public Policy Networks, 16 IND. J. GLOBAL LEGAL STUD. 605, 613-17 (2009). 
autonomy enforced through territorially based enforcement units. ${ }^{88}$

\section{B. An Amalgamation of Governments: The Multinational Corporation}

Societal constitutionalism, then, represents an articulation of a general framework of governance power that is not dependent-that is not grounded in the first instance - on the state as the model from which governance and its institutionalization is understood and shaped. The constitutional natures of nonstate organizations are revealed beyond the veiling presumptions of the state system. ${ }^{89}$ Like states, these organizations comprise internally coherent, closed, self-reflexive systems grounded in a set of norms that provide the basis of systemic constitution and the filter through which communication with outside systems may be effectuated.90

Among the most interesting of these nonstate organizations is the multinational corporation: a society that is both self-constituted and embedded at the center of a web of governance rules from which these enterprises draw to develop their own autonomous and autonomously applied governance systems. ${ }^{91}$ Self-constitution is possible precisely because the multinational corporation thrives in governance spaces between states, beyond international law, and among both, ${ }^{92}$ operating conditions made possible under globalization. ${ }^{93}$

88. Backer, supra note 66 , at 117 ("It also suggests that beyond organizing norms and legitimating processes that avoid arbitrary and personal capture of power, constituting power can be organized simultaneously under any number of normative (value) frameworks.").

89. By veiling presumptions, I mean the set of basic premises that tend to obscure the privilege built into the system in favor of states. These presumptions build a sense that the subordination of enterprises and other organizations ot states is "natural" and that "law" produced by states is "naturally" the touchstone for legitimate expression of a popular will. See Larry Catá Backer, On the Tension between Public and Private Governance in the Emerging Transnational Legal Order: State Ideology and Corporation in Polycentric Asymmetric Global Orders (Apr. 16, 2012), available at SSRN: http://ssrn.com/abstract=2038103 or http://dx.doi.org/10.2139/ssm.2038103. For an analysis of a similar autonomous organism, Gap, Inc., see generally Backer, supra note 74.

90. This touches on what Gunther Teubner describes as systemic hypercycles and ultracycles. See Teubner, supra note 40, at 634 ("A hypercycle emerges when communicative operations within a closed network form cycles that are interlinked in a circular way. In contrast, an ultracycle emerges when a cycle of mutual perturbations is developed between closed networks.").

91. See, e.g., id. at 621-28.

92. See Larry Catá Backer, The Autonomous Global Corporation: On the Role of Organizational Law Beyond Asset Partitioning and Legal Personality, 41 TULSA L. REV. 541 (2006) (arguing that the nexus of multinational enterprises and globalization provides 
Self-regulation follows from the application of the territorial principle, coupled with the possibilities of enterprise autonomy reinforced by asset partitioning regimes, self-ownership, and juridical personhood. An autonomous legal subject, responsible for its own obligations and able to direct itself can, by distributing its operations in accordance with the benefits of particular territorially limited legal regimes, effectively choose the mix of regulation to which it will submit itself. It follows that such an enterprise can regulate itself. A fully self-conscious autonomy is now complete. ${ }^{94}$

The embedding of multinational corporations within multiple and polycentric governance structures can be identified from out of the principal regulatory frameworks within which they operate. The first framework form includes internal systems of supply chain governance created by large multinational enterprises. ${ }^{95}$ The second framework form is the emerging system of soft law governance principles ${ }^{96}$ developed under the auspices of the Organization for Economic Cooperation and Development (OECD), and, principally, the OECD's Guidelines for Multinational Enterprises.97 The third form is the principles-based U.N. Guiding Principles for Business and Human Rights, which details a human rights due diligence framework for the regulation of the human rights obligations of multinational

a foundation for the emergence of self-conscious, autonomous, self-regulating economic enterprises).

93. See, e.g., Paul Schiff Berman, Federalism and International Law Through the Lens of Legal Pluralism, 73 Mo. L. REV. 1151 (2008); Kevin T. Jackson, The Normative Logic Of Global Economic Governance: In Pursuit Of Non-Instrumental Justification For The Rule Of Law And Human Rights, 22 MINN. J. INT'L L. 71. (2013).

94. Id. at 561 .

95. See generally Larry Catá Backer, Economic Globalization and the Rise of Efficient Systems of Global Private Law Making: Wal-Mart as Global Legislator, 39 CoNN. L. REV. 1739 (2007); Tim Bartley, Institutional Emergence in an Era of Globalization: The Rise of Transnational Private Regulation of Labor and Environmental Conditions, 113 AM. J. Soc. 297 (2007).

96. See, e.g., Martin Marcussen, OECD Governance Through Soft Law, in SoFT LAW IN GOVERNANCE AND REgULATION 103 (Ulrika Mörth ed., 2004); David Weissbrodt, Keynote Address: International Standard-Setting on the Human Rights Responsibilities of Businesses, 26 BERKELEY J. INT'L L. 373 (2008).

97. See Org. for Econ. Co-Operation \& Dev. [OECD], OECD Guidelines for Multinational Enterprises: 2011 Edition (May 25, 2011), available at http://www.oecd.org/ daf/internationalinvestment/guidelinesformultinationalenterprises/48004323.pdf [hereinafter OECD Guidelines]. 
corporations, 98 elaborated by John Ruggie, the United Nation's Secretary General Special Representative. ${ }^{99}$

Self-referential governance communities are narrowly constructed, and functionally differentiated communities. ${ }^{100}$ Functional differentiation suggests a limited framework of governance. Nonstate governance systems have a limited range. Functional differentiation also suggests a simultaneous overlapping of governance. At the same time, these are new and fragile systems. They are not fully developed. They may change. They have their systems sociology. ${ }^{101}$ But they also produce a space within their demarcated functionality that is constitutionally sufficient for governance. This space is constituted institutionally through a governance apparatus grounded in rule of law principles, ${ }^{102}$ in the sense of both process rule of law (systems created that legitimate the operations of the apparatus on the basis of rules for producing rules and enforcing them) and substance rule of law (rules are created in accordance with a process in which the members participate and reflect shared values that reflect community preferences). ${ }^{103}$

So constituted, the multinational corporation operates substantially like the state, though a state without a territory. ${ }^{104}$ It responds to the desires of its citizens, investors, and consumers through the production of policy and behaviors designed to enhance shareholder value and consumer demand. Shareholder desires are also affected by a normative framework exogenous to the multinational-one memorialized in binding and nonbinding instruments of international and national law, as well as other normative standards, sometimes bound up in concepts

98. See Special Representative of the Secretary-General on the Issue of Human Rights \& Transnational Corps. \& Other Bus. Enters., Guiding Principles on Business and Human Rights: Implementing the United Nations "Protect, Respect and Remedy" Framework, Human Rights Council, U.N. Doc. A/HRC/17/31 (Mar. 21, 2011) (by John Ruggie), available at http://www.business-humanrights.org/media/documents/ruggie/ruggie-guiding -principles-21-mar-2011.pdf.

99. See John Gerard Ruggie, Business and Human Rights: The Evolving International Agenda, 101 AM. J. INT'L L. 819 (2007).

100. See Backer, supra note 74.

101. See generally NIKLAS LUHMANN, SocLAL SYSTEMS, (John Bednarz, Jr. \& Dirk Baecker trans., Stanford Univ. Press 1995) (1984) (reproducing the new systems theory of self-reference within sociology).

102. See Terry Collingsworth, Beyond Public Relations: Bringing the Rule of Law to Corporate Codes of Conduct in the Global Economy, 6 CORP. GOVERNANCE 250 (2006).

103. Consider in this light the apparatus of a company like Gap, Inc., described in Backer, supra note 74, at 509-23.

104. Jean-Philippe Robé, Multinational Enterprises: The Constitution of a Pluralistic Legal Order, in GloBAL LAW WITHOUT A STATE, supra note 26, at 45, 45-47, 52-56. 
of corporate social responsibility and human rights. ${ }^{105}$ These policies are affected within the entity and its supply chain through contracts of a regulatory character. Compliance is enforced directly by the entity and also monitored by outsiders, principally civil society elements, and to some more remote extent, the state and other public actors. ${ }^{106}$ The threat of state intervention is also a disciplinary force. ${ }^{107}$ Civil society actors gain legitimacy in their enforcement function through relationships with the media-an organ that is at once both a producer of similar norms within its own enterprise and a producer of "sanctioned" information. ${ }^{108}$ But civil society also competes with the corporate regulator in the construction of investor and consumer tastes

105. See, e.g., Florian Wettstein, Beyond Voluntariness, Beyond CSR: Making a Case for Human Rights and Justice 114 BUS. \& Soc'Y REv. 125 (2009). "For several decades now the term 'corporate social responsibility' has been used in this context to describe a mechanism by which companies take responsibility for their actions and encourage a positive impact through its activities on, inter alia, human rights." COUNCIL OF EUROPE, Steering CommitTee on Human Rights, Human Rights and Rule of Law, Corporate Social Responsibility in the Field of Human Rights, Presentation, available at http://www.coe.int/t/dghl/standardsetting/hrpolicy/other_committees/hr_and_business/defa ult_EN.asp. For the Report, see STEERING COMMITTEe For HuMAN RIGHTS (CDDH), Feasibility Study On Corporate Social Responsibility In The Field Of Human Rights, 76 the meeting Strasbourg 27-30 Nov. 2012, Addendum VII CDDH(2012) R76, available at http://www.coe.int/t/dghl/standardsetting/hrpolicy/other_committees/hr_and_business/Doc uments/CDDH\%282012\%29R76_AddendumVII_EN.pdf.

106. See discussion, Section II, infra. There are emerging NGOs the primary purpose of which is to monitor compliance with internally developed or third party standards. This is the case, for example, of COVERCO, the Commisison for the Verification of Codes of Conduct, operating in Guatemala. What is COVERCO?, COVERCO, available at http://www.coverco.org.gt/e_index.html (last visited Aug. 17, 2013). The Fair Labor Association website nicely explains the three-part nature of private enforcement in a supply chain context: (1) standard setting; (2) monitoring; and (3) technical assistance. See Our Work, Protecting Workers' Rights Worldwide, FAIR LABOR ASSOCIATION, available at http://www.fairlabor.org/our-work. On the trend, generally, toward private enforcement, see, for example, Anne van Aaken, Trust, Verify, Or Incentivize? Effectuating Public International Law Regulating Public Goods Through Market Mechanisms, 104 AM. SoC'Y INT'L L. Proc. 153 (2010); Errol E. Meidinger, 'Private" Environmental Regulation, Human Rights, And Community 7 BUFF. ENVTL. L.J. 123 (2000).

107. And states operate at the periphery of supply chain governance. See, e.g., Peder Michael Pruzan-Jorgensen, Regulating Supply Chain Sustainability: What Would Have Been Unthinkable Only a Few Years Ago is Now the Order of the Day, GUARDIAN SUSTAINABLE BUS. (Sept. 12, 2011, 11:51 PM), http://www.guardian.co.uk/sustainablebusiness/blog/regulating-supply-chain-sustainability (describing some tentative and precisely narrow extensions of home state law to the supply chain relations of multinationals under the 2011 U.K. Bribery Act (bribery); the U.S. Dodd-Frank Act of 2010 (conflict minerals); the California Transparency in Supply Chain Act (slavery and human trafficking); and the EU Flegt Law (illegally logged timber)).

108. Consider in this light the apparatus of a company like Gap, Inc., described in Backer, supra note 74, at 509-23. 
and sometimes participates with the corporate entity in the construction of its regulatory standards for its supply chain. ${ }^{109}$ Taken together, what is produced is a complete governance framework operating beyond the territory of the state but also within a very narrow governance space.

At the same time, the community of multinational corporations, as a functionally differentiated community, may construct a self-referencing and autonomous regime of governance, though very narrowly focused, which is free of substantial state interference, except as a foreign body with which relations must be maintained. ${ }^{110} \mathrm{It}$ is in this sense that the old foundational notions of territoriality, as the marker par excellence of jurisdiction, lose coherence. ${ }^{111}$ The territory of norm creation and enforcement within and among corporations can be conceived as bounded by the territory of the operations of that community. The extra-territorial is that which lies beyond the normative framework of corporate governance, but the prime referent is no longer geography. It is in that sense that one understands the receding of the state from governance.

The OECD system of principles for the management of corporate behavior beyond the domestic law of states creates a three-dimensional governance "space" through networks of soft law systems developed by complex partnerships between states, international organizations that serve them and global actors, and the global actors that form the core of the regulatory community. 112 The clearest example is drawn from the recent work of the OECD's National Contact Point system for the enforcement of global soft law frameworks that radiate out from the

109. See, e.g., Erika N. Sasser et al., Direct Targeting as an NGO Political Strategy: Examining Private Authority Regimes in the Forest Sector, Bus. \& PoL., Dec. 2006, at 1, available at http:// www.bepress.com/bap/vol8/iss3/art1. See also Tim Bartley, Institutional Emergence in an Era of Globalization: The Rise of Transnational Private Regulation of Labor and Environmental Conditions, 113 AM. J. SocIOL. 297, 300, 319 (2007) (regarding campaigns against Nike).

110. See A. Claire Cutler, Private International Regimes and Interfirm Cooperation, in The Emergence of Private Authority in Global Governance 23 (Rodney Bruce Hall \& Thomas J. Biersteker eds., 2002).

111. See Gefion Schuler, Effective Governance Through Decentralized Soft Implementation: The OECD Guidelines for Multinational Enterprises, 9 GERMAN L.J. 1753 (2008) (proposing that effective governance is accomplished through multilevel partnership and decentralized soft-mediation based implementation).

112. And thus seeks to rebut the early conceptual critique: "[S]oft law expresses a preference and not an obligation that states should act, or should refrain from acting, in a specified manner. The underlying assumption is that behavior, or forbearance from behavior, in accordance with this preference will be directly beneficial to states." JOSEPH GOLD, INTERPRETATION: THE IMF AND INTERNATIONAL LAW 301 (1996). This governance space is sometimes understood as "spaceless" in the sense that it moves governance beyond territory, and thus beyond the premises that constrain lawmaking in the state system. See, e.g., Backer, supra note 81; Backer, supra note 89. 
OECD's Guidelines for Multinational Corporations. ${ }^{113}$ These principles tie autonomous multinational regulatory systems to the law systems of states in which they operate, but at the same time, institutionalize a stateless space within which corporations may be subject to substantive norm frameworks developed by public bodies. ${ }^{114}$ These frameworks draw their standards from multiple sources for the construction of an autonomous framework of governance that is made applicable to actors as a supplement to their obligations under the law-systems of states asserting territorial jurisdiction, ${ }^{115}$ much like Ralf Michaels suggests for lex mercatoria. ${ }^{116}$

The U.N. Guiding Principles for Business and Human Rights follow the pattern of OECD principles and rules but focus on the activities of business with human rights impacts. They do, however, recognize the polycentricity of business conduct with respect to human rights impact and specifically acknowledge a space within which corporations may act autonomously but in compliance with normative frameworks developed in the "constitutional principles" embraced by corporations, as endorsed by their investors and consumers, and as expressed in international law and norms. ${ }^{117}$ More importantly, the Guiding Principles also establish a

113. See OECD Guidelines, supra note 97 , at 67-78.

114. See, e.g., U.K. Nat'l Contact Point for the OECD Guidelines for Multinational Enters., Initial Assessment by the UK National Contact Point for the OECD Guidelines for Multinational Enterprises: Survival International and Vedanta Resources plc, BUSINESS \& HuMAN Rights ResourCe CENTRE (Mar. 27, 2009), http://www.businesshumanrights.org/Links/Repository/969215; U.K. Nat'l Contact Point for the OECD Guidelines for Multinational Enters., Final Statement by the UK National Contact Point for the OECD Guidelines for Multinational Enterprises: Complaint from Survival International Against Vedanta Resources plc, BUSINESS \& HUMAN RIGHTS RESOURCE CENTRE (Sept. 25, 2009), http:/www.businesshumanrights.org/Links/Repository/266990; U.K. Nat'l Contact Point for the OECD Guidelines for Multinational Enters., Statement by the United Kingdom National Contact Point (NCP) for OECD Guidelines for Multinational Enterprises (NCP): Das Air, Gov.UK (July 21, 2008), http://www.berr.gov.uk/files/file473 46.doc; U.K. Nat'l Contact Point for the OECD Guidelines for Multinational Enters., Final Statement by the UK National Contact Point for the OECD Guidelines for Multinational Enterprises: Afrimex (UK) Ltd, Gov.UK, (Aug. 28, 2008), http://www.berr.gov.uk/files/file 47555.doc.

115. See Amitai Aviram, A Paradox of Spontaneous Formation: The Evolution of Private Legal Systems, 22 YALE L. \& PoL'Y REV. 1 (2004).

116. See generally Ralf Michaels, The True Lex Mercatoria: Law Beyond the State, 14 IND. J. GLOBAL LEGAL STUD. 447 (2007) (arguing that the lex mercatoria heralds the shift in global law from segmentary differentiation in different national laws to a functional differentiation, as a law beyond the state).

117. Professor Ruggie noted early in the process of Guidelines formulation: The "protect, respect and remedy" framework lays the foundations for generating the necessary means to advance the business and human rights agenda. It spells out differentiated yet complementary roles and responsibilities for states and companies, and it includes the element 
mechanism for communication between autonomous governance systems-one internal to the constituted corporation and the other external and affecting corporate operations within defined, but spatially-limited territories. ${ }^{118} \mathrm{Mr}$. Ruggie suggests that multinational corporations can occupy multiple regulatory spaces that only together define a complete governance universe- one in which both law systems and norm systems ${ }^{119}$ exist in a complex set of entwined horizontal relationships. That leaves Mr. Ruggie in essentially new territory that rejects the monopoly of law systems within states and the conception of norm systems as nonbinding. As incompatible systems, law and norms must effectively find a way to communicate and to harmonize values and relevance for their constituting communities, whether these are citizens, consumers, employees, or investors.

The importance of polycentric governance is also emphasized by this system. ${ }^{120}$ Yet, polycentric governance tends to obscure the reality of emerging autonomous governance, mistaking communication among systems with limited jurisdictions for competitions for supremacy within a single vertically-oriented arrangement of power. ${ }^{121}$ Still, at least within the context of the multinational corporation, it is possible to speak of governance without government, ${ }^{122}$ where the latter term is

of remedy for when things go wrong. It is systemic in character, meaning that the component parts are intended to support and reinforce one another, creating a dynamic process of cumulative progress-one that does not foreclose additional longer-term meaningful measures.

Special Representative of the Secretary-General on the Issue of Human Rights and Transnational Corporations and Other Business Enterprises, Opening Remarks on the Consultation on Operationalizing the Framework for Business and Human Rights, Business \& Human RightS ResourCe CenTRe (Oct. 5, 2009), http://www.businesshumanrights.org/Links/Repository/105128.

118. See Gunther Teubner, The Corporate Codes of Multinationals: Company Constitutions Beyond Corporate Governance and Co-Determination, in CoNFLICT OF LAWS

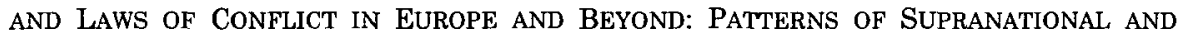
TRANSNATIONAL JURIDIFICATION 203 (Rainer Nickel ed., 2010) (exploring intermeshing).

119. Cf. Lisa Bernstein, Opting Out of the Legal System: Extralegal Contractual Relations in the Diamond Industry, 21 J. LEGAL STUD. 115 (1992); Robert C. Ellickson, Law and Economics Discovers Social Norms, 27 J. LEGAL STUD. 537, 540 (1998).

120. See generally Backer, supra note 36.

121. See Jörg Friedrichs, The Meaning of New Medievalism, 7 EUR. J. INT'L REL. 475, 475 (2001) ("[M]edievalism is defined as a system of overlapping authority and multiple loyalty, held together by a duality of competing universalistic claims. . . . [T] The post-international world is characterized by a complicated web of societal identities, held together by the antagonistic organizational claims of the nation-state system and the transnational market economy.").

122. For the classic formulation, see GovernanCE Without Government: ORDER AND ChANGe IN WoRld Politics (James N. Rosenau \& Ernst-Otto Czempiel eds., 1992); Backer, supra note 95. 
meant to refer to the state. It is also possible to speak, to some extent, of government without a state as an element in the governance of multinational regulation. What emerge within the corporation are "self-sufficient, self-perpetuating and internally autonomous system[s] of social relations" contained within the framework of its functionally differentiated objectives. ${ }^{123}$ It is possible to see the construction of autonomous and self-referential social-norm systems outside of the shadow of the territorially-bound law-systems of states, but these systems also exist within a space richly populated by other systems of social relations, the regulatory force of some of which affect the internal and external relations of the self-constituted corporate society.

\section{Is THERE A SUN AROUND WHICH SOCIETAL CONSTITUTIONS ORBIT?}

"The philosopher casts his eye over existence, and wishes to give it a new standard value; for it has been the peculiar task of all great thinkers to be law-givers for the weight and stamp in the mint of reality." 124 For social organizations, constitutionalism offers the promise of providing something approaching that principle. Yet organizing principles are personal to the organism that struggles against or accepts them. Only the struggle remains the same-over and over. These open systems of multiple cycles constitute the matrix within which the hermeneutical projects of interpretation can occur and foundations can be established, maintained, problematized, destroyed, and replaced. But globalization and the emerging societal constitutions of nonstate actors have contributed to the complexity of systemic cyclicity. ${ }^{125}$

One can test the utility of this emerging understanding of the governance frameworks of the globalized world order by considering an example: the supply chain transparency policies of Apple Incorporated. The object is to understand not only how Apple is not merely self-constituted autonomously of the states in which it operates, but to suggest the importance of communication, conflict, and catastrophe in the process of internal and external communication with other actors.

123. M. G. SMITH, CORPORATIONS AND SOCIETY 248 (1974).

124. Friedrich Nietzsche, Thoughts Out Of Season Part II: The Use And Abuse Of History \& Schopenhauer As Educator, in THE COMPLETE WORKS OF FRIEDRICH NIETZSCHE VoL. II 130 (Oscar Levy, ed., Adrian Collins, M.A., trans., 1909).

125. See, e.g., Ronen Shamir, Corporate Social Responsibility: Towards a New Market-Embedded Morality?, 9 THEORETICAL INQUIRIES IN LAW 371 (2008) ("governance is premised on facilitating 'private' forms of authority: corporations, trade and technical-professional associations, accountancy and credit rating agencies, and standard-setting organizations are all increasingly assuming regulatory roles and intensively experimenting with novel forms of legality." Id. at 377). With these, of course, come distinctive forms of regulation, many without the backing of the state. Id. at 378 . 
The Apple example also provides a context for observing, in operation, the dynamic element of societal constitutionalism. It suggests that both Lindahl's spatiality and Teubner's permeability now apply within organisms that do not stand still long enough for the theorist to contemplate its character in motionless space. It is the elements of motion, space, and permeability that suggest both the utility of societal constitutionalism and its limits. It also suggests that there may be a strong difference between state and nonstate governance constitutions. Public law based constitutionalism, like much in Western law, posits equilibrium as the basic state of system operation. ${ }^{126}$ Disequilibrium is viewed as a temporary state leading to equilibrium, which is a sign of system integrity and success. Dynamic societal constitutionalism posits the opposite for private governance constitutionalism-disequilibrium is the equilibrium state. ${ }^{127}$ Constitutional systems that are permeable, structured within intangible borders that are constantly being redrawn, define and redefine themselves over very short time horizons. ${ }^{128}$ Systemic integrity is grounded in the constitutional norms within which a governance unit is organized, but even these are connected to frameworks of common standards shared by governance unit stakeholders. Dynamic societal constitutionalism produces a "quick tempo" application of public law "living constitution" norms but with the

126. See, e.g., Rolf H. Weber \& Shawn Gunnarson, A Constitutional Solution for Internet Governance, 14 COLUM. SCI. \& TECH. L. REV. 1 (2013) ("Constitutional principles, binding leaders, and stakeholders alike generally establish stability by assuring a degree of predictability and encouraging legitimate expectations by those they govern." Id. at 63 (citing in part Niklas Luhmann, Verfassung als evolutionäre Errungenschaft, 9 RECHTSHISTORISCHES J., 176, 181 (1990).); Imaculada Baviera, Employment Stability In Spanish Labor Law: Between Regulatory Tradition And Social Reality, 34 COMP. LAB. L. \& POL'Y $J 677$ ("A traditional principle in Spanish labor law is employment stability."). See also Alexander Orakhelashvili, Legal Stability and Claims of Change: The International Court's Treatment of Jus ad Bellum and Jus in Bello, 75 NORDIC J. INT'L L. 371, 372 (2006) (with respect to state claims of legal change because of the particular circumstances of their claims under international law, "[t]he claims of legal change attendant to such developments contradict the idea that the legal framework must be viewed as coherent and predictable, not liable to change at each and every instance of the exercise of power.").

127. See discussion, infra, Part III.

128. See Inger-Johanne Sand, Polycontextuality as an Alternative to Constitutionalism, in TRANSNAT'L GOVERnANCE AND CONSTITUTIONALISM 41 (Christian Joerges, Inger-Johanne Sand \& Gunther Teubner, eds., 2004). Cf. Boaventura de Sousa Santos, Law: A Map of Misreading. Toward a Postmodern Conception of Law, 14(3) J. L. \& Soc. 279-302 (1987) ("different legal spaces superposed, interpenetrated and mixed," id. at 293); Julia Black, Constructing and Contesting Legitimacy and Accountability in Polycentric Regulatory Regimes (Feb. 2008), LSE Legal Studies Working Paper No. 2/2008, available at $\mathrm{http}: / / \mathrm{ssrn}$.com/abstract $=1091783$. 
addition of the private governance dimension. ${ }^{129}$ Apple suggests the contours of that dynamism and the possibility of preserving system integrity even within structures of communication, permeability, and three-dimensional governance spaces.

\section{A. Apple and Governance Catastrophe: A Story of Crisis and Transformation in Three Dimensional Governance Space}

Apple can be understood as a self-constituted organization existing autonomously of any one state. ${ }^{130}$ Its scope of authority is bounded by its business objectives for which it is accountable to its shareholders and consumers. Its institutional autonomy is bound up in the apparatus of its corporate structures from which it derives its regulatory authority through contracts within the value chain of its activities. Its aggregate operations, assets, and markets are not completely directed by any state, though all may be subject to the rules of any state in which Apple chooses to operate. ${ }^{131}$ It can choose the style of its own constitution even as it can choose the locus of the territory within which it will place everything from its principal offices to its smallest operations. It can also determine the form of those relationships. Lastly, within the bounds of its authority, in the relationships with its suppliers, it has developed an effective power to settle disputes. ${ }^{132}$ Apple's organization has a constitutional element-the organizing principles of its government apparatus and the rules for the operation of the governance power vested in this organization. The normative elements of its rule systems are themselves grounded in standards and values that are generally accepted ${ }^{133}$ and reflect the value standards of its investors and consumers. ${ }^{134}$ These are values that Apple then shares uniformly with its suppliers and their workers (the universe of their dependent

129. Cf. Winfried Brugger, Legal Interpretation, Schools of Jurisprudence, and Anthropology: Some Remarks from a German Point of View, 42 AM. J. CoMP. L. 395, 410-16 (1994).

130. Cf. Teubner, supra note 40 .

131. Generally on the jurisdictional limits of multinational regulation, see PETER MUCHLINSKI, MULTINATIONAL ENTERPRISES AND THE LAW 90-172 (1999).

132. See, e.g., We Believe in Accountability-for Our Suppliers and for Ourselves, APPLE, http://www.apple.com/supplierresponsibility/auditing.html (last visited Apr. 8, 2013) (describing Apple's auditing system for enforcing its "supplier code of conduct").

133. See, e.g., Supplier Responsibility at Apple, APPLE, http://www.apple.com/supplier responsibility/ (last visited Apr. 8, 2013) (describing Apple's expectations with respect to its suppliers' working conditions and environmental impacts).

134. See, e.g., Environmental Progress, APPLE, http://www.apple.com/environment/progr ess/ (last visited Apr. 8, 2013) (describing Apple's efforts to reduce its environmental impacts). 
populations) through aggressive education and socialization programs. ${ }^{135}$ The normative elements are grounded in legitimacy and touch on those structures that make it possible both to "see" the self-constituting enterprise and to treat it, both inside and outside, as something legitimately apart from its stakeholders-that is to "feel" it. ${ }^{136}$ Apple is structured as a system of taxonomy and legitimation that is grounded in a set of normative assumptions about the purpose of government and its connection to governance. Apple's constitution, then, produces a self-referencing system whose effects and projections outward can be felt and understood as legitimate. Its internal rules are grounded in values that reflect behavior norms that are impersonal and process based (the rule of law of Apple). ${ }^{137}$

Apple, Inc. sits at the top of a vast supply chain through which it conceives, designs, manufactures, assembles and distributes a large product line to consumers' world wide. ${ }^{138}$ While Apple may participate

135. See When People Gain New Skills and Knowledge, They Can Improve Their Lives, APPLE, http://www.apple.com/supplierresponsibility/education-and-development.html (last visited Apr. 8, 2013) (describing educational resources for workers in Apple's supply chain).

136. See generally APPLE SUPPLIER RESPONSIBILITY: 2012 PRogress RePorT, APPLE, (2012), available at http://images.apple.com/supplierresponsibility/pdf/Apple_SR_2012_Pro gress_Report.pdf.

137. This is reflected in the construction of its Supplier Code of Conduct-the constitutional framework of its supply chain relationships:

The Supplier Code of Conduct prohibits all types of involuntary labor, such as slavery, indentured or bonded labor, child labor, and prison labor. Our suppliers certify compliance with the local laws applicable to their operations, including any slavery and human trafficking laws, and we verify compliance by conducting rigorous audits of their facilities. Beyond auditing, we provide our employees who are directly responsible for supply chain management with training on involuntary labor and human trafficking issues to reinforce our prevention efforts, and we hold them accountable for complying with our standards.

Labor and Human Rights, APPLE, originally available at http://www.apple.com/supplier responsibility/code-of-conduct/labor-and-human-rights.html, now cached at http://fireballe d.org/linked/2012/03/20/monthly-reporting/ (last visited July 12, 2013) (describing Apple's efforts to prohibit practices that threaten the rights of workers, even when local laws and customs permit such practices relating specifically to indentured migrant labor).

138. In its 2012 Annual Report in SEC Form 10K, Apple stated:

Substantially all of the Company's hardware products are manufactured by outsourcing partners that are located primarily in Asia. A significant concentration of this manufacturing is currently performed by a small number of outsourcing partners, often in single locations. Certain of these outsourcing partners are the sole-sourced suppliers of components and manufacturers for many of the Company's products. Although the Company Works closely with its outsourcing partners on manufacturing schedules, the Company's operating results could be adversely affected if its outsourcing partners were unable to meet their production commitments. The Company's purchase 
directly in parts of this chain of production, it has outsourced much of its production to other autonomous enterprises. Apple had long operated its own corporate social responsibility governance system through its supply chain. 139 The constitution of this regulatory system was the Apple Supplier Code of Conduct. ${ }^{140}$ The Code itself is grounded in international hard and soft law, much of which has not been transposed into the domestic law of the United States, much less the domestic law of host states in which suppliers may be operating. ${ }^{141}$ Unlike other multinational corporations with large supply chain operations, Apple has not moved to incorporate within its international governance much of the governance systems developed by international organs-and specifically those of the U.N. Global Compact, and the Guiding Principles. ${ }^{142}$ Nor did it embrace third party nonstate (private sector) corporate social responsibility (CSR) related reporting efforts, such as

commitments typically cover its requirements for periods up to 150 days.

Annual Report Form 10K 2012, APPLE, INC. at 7, available at http:/files.shareholder.com/ downloads/AAPL/2589956175x0xS1193125-12-444068/320193/filing.pdf.

139. See APPLE, supra note 136, at 3 ("Our suppliers must live up to Apple's Supplier Code of Conduct as a condition of doing business with us. Drawing on internationally recognized standards, our Code lays out Apple's expectations in the areas of labor and human rights, worker health and safety, the environmental impact, ethics, and management systems. We insist that our manufacturing partners follow this Code, and we make sure they do by conducting rigorous audits with the help of independent experts."). A more detailed analysis is the subject of Section II.B., infra.

140. Apple Supplier Code of Conduct, APPLE INC., available at http://www.apple.com/ supplierresponsibility/pdf/Apple_Supplier_Code_of_Conduct.pdf. Though the Supplier Code was structured as part of the contractual relations between Apple and its suppliers, it was essentially regulatory in nature. "Apple requires that Suppliers implement this Code using the management systems described below. Apple may visit (and/or have external monitors visit) Supplier facilities, with or without notice, to assess compliance with this Code and to audit Supplier's wage, hour, payroll, and other worker records and practices. Violations of this Code may result in immediate termination as an Apple Supplier and in legal action" $I d$.

141. This produces a communicative cyclidity at the heart of the embeddedness of societally constituted economic "territories" like that overseen by Apple, and traditional public regulatory space. See, e.g., Teubner, supra note 40 , at 634-35.

142. It should be noted though that these are offered usually as frameworks around which conduct expectation can be drawn, rather than as fully developed regulatory standards. For example, the FAQs of the Global Compact suggest, "The Global Compact is not a code of conduct. Rather, it offers a policy framework for organizing and developing corporate sustainability strategies while offering a platform-based on universal principles-to encourage innovative initiatives and partnerships with civil society, governments and other stakeholders." FAQs, Why should a company that has already established its own code of conduct participate in the Global Compact?, U.N. GLOBAL COMPACT, at 6, available at http://www.unglobalcompact.org/AboutTheGC/faq.html last visited Sept. 15, 2013). Others, like the OECD Guidelines, are developed as more regulatory in structure. 
the systems offered through GRI. ${ }^{143}$ Instead, Apple sought to create and maintain internally developed reporting and behavior standards. This unique regulatory code was developed with reference to a number of international public and private standards, ${ }^{144}$ but reflected the way in which inter-systemic structural coupling both opens self-constituted social systems to other systems, and the way in which those communications are filtered and absorbed to preserve systemic integrity.

The Code specifies behavior standards and expectations in the areas of labor, human rights, worker health/safety, environmental impact, ethics, and management. ${ }^{145}$ Apple reports the results of its monitoring in an annual Apple Supplier Responsibility Progress Report. ${ }^{146}$ These reports suggest the working of an autonomous self-constituted system of regulatory governance built around Apple and it suppliers, investors, and consumers, who play a central role, supported by nongovernment organizations (NGOs) and the media, 147 framed within the economic activities of Apple's business. But the engine for regulatory movement is triggered by constant communication that in its most transformative aspects take on the character of Teubner's collisions, ${ }^{148}$ within a the context of polycentric spatial jurisdictions, as Lindahl describes. ${ }^{149}$

143. The Global Reporing Initiative "is a non-profit organization that works towards a sustainable global economy by providing sustainability reporting guidance. "See About Us, GRI, available at https://www.globalreporting.org/information/about-gri/what-isGRI/Pages/default.aspx.

144. The Apple Supplier Code provides that it is modeled on and contains language from the Electronic Industry Code of Conduct. Recognized standards such as the Universal Declaration of Human Rights (UDHR), and standards issued by organizations such as the International Labour Organization (ILO), Social Accountability International (SAI), and the Ethical Trading Initiative (ETI) were used as references in preparing this Code and may be useful sources of additional information. A complete list of references is provided at the end of this Code. As an extension of the Code, Apple maintains a series of detailed Standards that clarify our expectations for compliance

Apple Suppler Code of Conduct, APPLE INC., at 1, available at http://images.apple.com/ supplierresponsibility/pdf/Apple_Supplier_Code_of_Conduct.pdf (last visited Sept. 15, 2013). The Supplier Code of Conduct lists most of the well-known international public and private sources of standards of business conduct. Id. at 7-8.

145. See Supplier Responsibility at Apple, supra note 133.

146. APPLE, supra note 136. The 2012 Report includes the results of its audits (a private regulatory function within voluntary code systems). Earlier reports are also available at the Apple website.

147. Teubner, supra note 118, at 204.

148. See discussion, Part III, infra.

149. Id. 
Apple retained sole responsibility for monitoring compliance with its Code and for remediating breaches and assessing sanctions. ${ }^{150}$ Before January 2012 Apple consistently resisted pressure to disclose the environmental impact of their manufacturing process or open their supplier factories to auditors. ${ }^{151}$ Indeed, Apple's secrecy regarding its manufacturing and supplier arrangements has attracted media attention in the wake of recent violent incidents at Apple supplier factories in China and other Asian countries. ${ }^{152}$ In response to an early criticism by Greenpeace demanding greater transparency regarding the use of toxic chemicals in Apple products, a letter was published, signed by former Apple CEO Steve Jobs, providing limited details of Apple's internal efforts to reduce and remove toxic substances from its products. ${ }^{153}$ This was part of the emergence of a more public and comprehensive CSR effort by Apple, ${ }^{154}$ demonstrated by the publication on its website of a variety of different documents that instituted elements of independently governed transparency systems, while reassuring Apple shareholders that the corporation could safely and ethically monitor its own practices. ${ }^{155}$ In subsequent years, Apple has gradually expanded and changed its online CSR documentation, frequently disclosing additional procedures and imitating additional external standards to respond to different emerging criticism of the environmental and employment practices of its industrial suppliers and

150. The Supplier Code of Conduct permits Apple the power to monitor, assess and inspect suppliers for compliance. APPLE, supra note 136. It has the power to terminate its relationship with suppliers for violation of their Supplier Code and it compelled suppliers to "have a process for timely correction of any deficiencies identified by an internal or external audit, assessment, inspection, investigation, or review." Id. at 7.

151. "We continue to revise our Code based on our experience of auditing our suppliers and through discussions with stakeholder groups." Apple Supplier Responsibility 2010 Progress Report, APPLE INC., at 6, available at http://images.apple.com/supplier responsibility/pdf/Apple_SR_2010_Progress_Report.pdf. This suggests the operation of a tightly woven self-referencing communication cycle that is permeable but that has constituted itself independently of other governance structures with which it might also communicate. See Teubner, supra note 49.

152. See, e.g., Charles Duhigg \& David Barboza, In China, Human Costs Are Built into an IPad, N.Y. TIMES (Jan. 25, 2012), http://www.nytimes.com/2012/01/26/business/i eco nomy-apples-ipad-and-the-human-costs-for-workers-in-china.html?pagewanted=all\&_r=0.

153. See Jim Dalrymple, Steve Jobs Outlines Plans for 'a Greener Apple', MACWORLD (May 2, 2007, 12:00 AM), http:/www.macworld.com/article/57680/2007/05/greenapple.htm 1.

154. See Steve Jobs, A Greener Apple, APPLE (May 2, 2007), http://images.apple.com/hot news/agreenerapple/docs/A_Greener_Apple.pdf.

155. See Supplier Responsibility at Apple, supra note 133. 
manufacturing partners. ${ }^{156}$ Although this material is now being supplanted by third-party oversight, Apple's self-managed corporate governance reporting is educational about the potential advantages and risks facing companies that choose a "go-it-alone" approach. ${ }^{157}$

The system worked reasonably well, but Apple, like other large multinational corporations, is vulnerable to reputation damage among consumers and investors in developed states. ${ }^{158}$ For Apple, that vulnerability was mediated by a regimen of internal transparency (between Apple and its suppliers) but external barriers to information. Before 2012, Apple had resisted any effort to mesh its corporate social responsibility regulatory frameworks with those developed by private or public actors. One of these is the Fair Labor Association (FLA), which describes itself as "a nonprofit organization dedicated to ending sweatshop conditions in factories worldwide."159 It seeks to meet this goal by "bringing together multiple stakeholders, calling for greater accountability and transparency from manufacturers, factories and others involved in global supply chains, and creating lasting solutions to exploitative labor practices." 160 Key to the work of FLA is the collaborative development of standards and the enforcement of a system of monitoring and reporting (transparency) of compliance. "FLA Participating Companies ... commit to promoting and complying with international labor standards throughout their supply chains[,]" both in the U.S. and overseas. ${ }^{161}$ Transparency and reporting are the the keys to the operation of this system. Companies that join the FLA commit to establishing internal systems for monitoring workplace conditions and maintaining Code standards, being part of a rigorous system of Independent External Monitoring (IEM), and public reporting on the conditions in their supplier factories. To ensure transparency, the results of the IEM audits are published on the FLA Web site in the form

156. These changes are reflected in Apple's Supplier Responsibility Progress Reports. A link to historical Reports is provided on the Apple website at http://www.apple.com/ supplierresponsibility/reports.html.

157. Another prominent example of the advantages of internal CSR practices is Wal-Mart, a company whose market leverage, emerging in part from its CSR development, has spawned an academic literature of its own. See, e.g., Yu Xiaomin \& Pun Ngai, Walmartization, Corporate Social Responsibility, and the Labor Standards of Toy Factories in South China, in WALMART IN CHINA 54 (Anita Chan ed., 2011).

158. See, e.g., Edmund R. Gray, and John M.T. Balmer, Managing Corporate Image and Corporate Reputation, 31(5) LONG RANGE PlaNNING 649-802 (October 1998).

159. FAIR LAB. AsS'N, http://oldsite.fairlabor.org/ (last visited Apr. 8, 2013).

160. Id.

161. Accreditation, FAIR LAB. ASS'N, http://www.fairlabor.org/accreditation (last visited Apr. 8, 2013). 
of tracking charts. ${ }^{162}$ But it was precisely to avoid the convergence of regulatory systems, and preserve the autonomy and control of its regulatory environment, within its supply chain, that probably accounted for Apple's proprietary approach to its own self-constitution. Though those structures were deeply enmeshed with other structures of business conduct, they remained separated from those developed by Apple.

Apple, Inc. also did not mesh its corporate social responsibility regimes with those of its downstream suppliers, irrespective of their size or power. One of them is Hon Hai Precision Industry Co., Ltd. ${ }^{163}$ Operating as Foxconn Technology Group ("Foxconn"), the company describes itself as "the most dependable partner for joint-design, joint-development, manufacturing, assembly and after-sales services to global Computer, Communication and Consumer-electronics (" $3 \mathrm{C}$ ") leaders. Aided by its legendary green manufacturing execution, uncompromising customer devotion and its award-winning proprietary business model, eCMMS, Hon Hai has been the most trusted name in contract manufacturing services (including CEM, EMS, ODM and CMMS) in the world."164 By 2012, Foxconn had grown into one of the largest corporate enterprises on earth. ${ }^{165}$ In addition to its work for others, Han Hai/Foxconn manufactures a substantial number of Apple products for sale and distribution elsewhere. ${ }^{166}$

162. What We Do, FAIR LAB. ASS'N, http://oldsite.fairlabor.org/what_we_do.html (last visited Apr. 8, 2013).

163. A website profile is available at $h$ ttp://www.foxconn.com/index_En.html. The Company explains that it is "Guided by a belief that the electronics products would be an integral part of everyday life in every office and in every home, Terry Gou founded Hon Hai Precision Industry Company Ltd., the anchor company of Hon Hai/Foxconn Technology Group in 1974 with US\$7,500, a devotion in integrating expertise for mechanical and electrical parts and an uncommon concept to provide the lowest 'total cost' solution to increase the affordability of electronics products for all mankind." Group Profile, HoN HAI/FOXCONN, available at http://www.foxconn.com/GroupProfile_En/GroupProfile.html (last visited Sept. 15, 2013).

164. Group Profile, Hon HAI/FoXCONN, supra note 164.

165. Foxconn reported that for 2012, it was ranked 43rd among Fortune Global 500 and 156th among Forbes Global 2000. See HoN HaI/FoxConN, Company Milestones, available $a t \mathrm{http}: / / \mathrm{www}$. foxconn.com/GroupProfile_En/CompanyMilestones.html (last visited Sept. 15, 2013).

166. "The Taiwan-based company is known as the world's largest electronics supplier, and also counts HP, Microsoft, Sony and other major tech vendors as its clients. Apple, however, makes up $40 \%$ to $50 \%$ of the company's revenues, according to analysts. Hon Hai helps build Apple's iPhone, iPad, iPod and Mac devices." Michael Kan, Apple Supplier Hon Hai Earns Record Annual Profit, COMPUTERLAND, Mar. 25, 2013, available at http://www.computerworld.com/s/article/9237884/Apple_supplier_Hon_Hai_earns_record_ annual_profit. 
Like other large companies, Foxconn had also developed its own autonomous corporate social responsibility philosophy, which it has institutionalized through policy. ${ }^{167}$ Like Apple's policies, it was based largely on the Electronic Industry Citizenship Coalition (EICC) Code of Conduct, ${ }^{168}$ covering labor, social, and environmental issues. ${ }^{169}$ Foxconn's CSR policies are made applicable to all aspects of its operations ${ }^{170}$ and are integrated into its management structure. ${ }^{171}$ Foxconn has made available CSR Reports for the years 2008-2011 on its website. ${ }^{172}$ Foxconn's 2008 CSR Report recognized the importance of CSR issues in the organization of corporate operations and the critical role that social actors played in the development of CSR structures and operations. ${ }^{173}$ Foxconn's vision consists of three parts, all of which

167. SER Introduction, HoN HAL/FOXCONN, available at http://ser.foxconn.com/Introduc tionShow.do.

Codes set out in this CoC policy were derived from three disciplined sources which are: a) the member obligations of the industrial associations and the EICC of which Foxconn is a member, and the international standard institutes to which Foxconn's business is related; b) the laws covering national regions where Foxconn deploys operations; and c) the internal leadership of Foxconn who determine voluntary upgrading of performance standards.

SER CoC, HON HAI/FOXCONN, available at http://ser.foxconn.com/GroupCocShow.do (last visited Sept. 15, 2013).

168. "Foxconn has been a member of the EICC since 2005. Foxconn established its SER committee to manage corporate social and environmental responsibility. Foxconn has released its own SER code of conduct, which is equivalent to the EICC CoC, to promote SER management." SER Introduction, supra note 167.

169. HON HaI/FOXCONN, SER Policy, SER Statement, available at http://ser.foxconn.com /PolicyShow.do (last visited Sept. 15, 2013).

170. Foxconn states on its website:

Foxconn incorporates SER into everyday business to insure health and safety, employee's rights and benefits, and environmental protection are fully implemented throughout the company. Foxconn's SER committee has set up a management system which complies with international standards, national laws, regulations, and customer requirements for the company's development and sustainable improvement

SER Policy, SER Statement, supra note 170.

171. See SER Organization, HON HAI/FOXCONN, available at http://ser.foxconn.com/Org DescShow.do (last visited Sept. 15, 2013).

172. CSR Annual Report, HON HAI/FOXCONN, available at http://ser.foxconn.com/View AnuReport.do?action=showAnnual (last visited Sept. 15, 2013).

173. "In 2007, Foxconn Technology Group established the Foxconn Global SER Committee (FGSC) to proactively work with stakeholders including customers, nongovernmental organizations (NGOs), and other interested groups on CSER issues. As a result of the committee's work, we have implemented a wide range of initiatives to improve our performance across the spectrum of corporate responsibility issues. Our progress on these issues is outlined in this report." 2008 Corporate Social and Environmental Responsibility Report (2008), FoxCONN TECH. GROUP, at 28, available at 
together emphasize a commitment to harmony for the profit of the company and the benefit of its stakeholders. ${ }^{174}$ Despite its substantial CSR programs and reports, there is no indication that either Han Hai or Apple took any steps to mesh their respective CSR programs. From Apple's perspective, Han Hai/Foxconn was contractually obligated to conform its operations to Apple's Supplier Code of Conduct. From Han Hai/Foxconn's perspective, its CSR program might be harmonized with that of Apple, but in any case, its workers would be subject to its own CSR policies, perhaps overlain with those of Apple, the law international law norms overlay the structures of a state's domestic legal order. ${ }^{175}$ Together, each served as an irritant to the other in the management of the supplier related operations of Han Hain/Foxconn. Both have been in communication (structurally coupled) with transnational private and public actors from which their respective CSR policies were derived. Lastly, each was deeply embedded in networks in which both states and private actors sought to monitor corporate compliance with their respective codes, supported in part by media supported by consumers ands investors who derive information about

http://ser.foxconn.com/downloadAttachment/8abe98dc3c5f940a013c84daf0240241/2008+Fo xconn+CSER+Annual+Report.pdf (last visited Sept. 15, 2013).

174. The Company has developed a specific philosophy:

"Since 1974, Hon Hai/Foxconn had always been guided by three Foxconnian visions; Through the most efficient "Total Cost Advantages" to make comfort of electronic products usage an attainable reality for all mankind; Through the proprietary one-stop shopping vertical integrated eCMMS model to revolutionize the conventional inefficient electronics outsourcing model; Through the devotion to greater social harmony and higher ethical standards to achieve a win-win model for all stakeholders including shareholders, employees, community and management.

About Foxconn, Business Philosophy, FoxCONN, available at http://www.foxconn.com/ GroupProfile_En/BusinessPhilosophy.html (last visited Sept. 15, 2013).

175. This relationship produced substantial differences in worker treatment even within Foxconn's Factory. A 2012 civil society report noted:

Interviews have revealed that workers who make Apple electronics make more money than those who work on other brands' products, though this certainly is related to how many overtime hours are worked. In our investigation, we came to learn that wages can be very different even over the same work time since workers make different brands of products. For example, in interviewing two workers from different cell phone departments who were working the same hours, the worker producing cell phones for a small brand-name company was earning only 2,500 RMB (\$397) per month, while the Apple worker earned 3,200 RMB (\$508).

Beyond Foxconn: Deplorable Working Conditions Characterize Apple's Entire Supply Chain, CHINA LABOR WATCH, $92-93$ (June 27, 2012), available at http://www.chinalabor watch.org/pdf/2012627-5.pdf. 
corporate compliance from these sources to aid them in their consumption and investment decisions. ${ }^{176}$

All of this would have remained a theoretical curiosity but for a series of shocks that occurred between 2006 and 2012 and that, by overwhelming Apple and Foxconn's CSR systems, threatened the foundations of their societal constitutions. In 2006, reports began to surface in the international press about terrible working conditions at Apple's supplier plants in China. Apple pledged a greater focus on monitoring and remediation. There was little more until 2010, when the wake of a long string of suicides by workers protesting working conditions at Han Hai/Foxconn's Shenzhen factories brought international attention to multiple layers of CSR standards that did not seem to work. ${ }^{177}$ The negative impact on Apple's image and Foxconn's reputation was immediate and substantial. ${ }^{178}$ "Foxconn says it is at its wits' end as to how to tackle the problem, and has even drafted in a Buddhist monk to try to purge its factories of evil spirits." 179 Apple's initial reaction, after the successful suicides of twelve employees at the Foxconn Shenzhen plant, was more offensive. ${ }^{180}$ Foxconn's approach was

176. Cf. Larry Catá Backer, Economic Globalization and the Rise of Efficient Systems of Global Private Law Making: Wal-Mart as Global Legislator, 39 CONN. L. REV. 1739 (2007).

177. The Economist reported:

Apple was expecting lots of publicity ahead of the international release of the iPad, its latest gadget, on May 28th-but not the sort it received in Hong Kong this week, which included the ritual burning of pictures of iPhones and calls for a global boycott. The protests were triggered by a series of suicides of employees of Foxconn, a subsidiary of Taiwan's Hon Hai Precision Industry Company, the world's largest "contract manufacturer."

Light and Death: Suicides at Foxconn, Economist, May 27, 2010, available at http:/www. economist.com/node/16231588.

178. Id.

179. Malcolm Moore, What Has Triggered the Suicide Cluster at Foxconn, TELEGRAPH, May 16, 2010, available at http://blogs.telegraph.co.uk/news/malcolmmoore/100039883/ what-has-triggered-the-suicide-cluster-at-foxconn/.

180. See Claudine Beaumont, Foxconn Suicide Rate is Lower Than in the US, Says Apple's Steve Jobs, TELEGRAPH, June 2, 2010, available at http://www.telegraph.co.uk /technology/steve-jobs/7796546/Foxconn-suicide-rate-is-lower-than-in-the-US-says-ApplesSteve-Jobs.html.

Jobs said Apple was "on top" of the situation, and that the company took its corporate and social responsibilities seriously. "We are all over this," he told delegates at the D8 technology conference in California. "We look at everything at these companies, and I can tell you a few things that we know: Foxconn is not a sweatshop. It's a factory, but they have restaurants and movie theatres. They've had some suicides and attempted suicides. They have 400,000 people there. The rate is under what the US rate is, but it's still troubling." Jobs said that there had been a spate of copycat suicides in Palo Alto, his hometown, and that Apple was working hard to get to the root of problems at Foxconn. 
more measured. "Foxconn Technology Group Chairman Terry Gou bowed deeply several times and apologized but also cautioned there was only so much his company could do."181 Foxconn also consulted with mental health professionals. ${ }^{182}$ By November 2010, Reuters was reporting that "the company has pledged to improve work conditions, increase pay, reduce overtime hours and build a string of giant new manufacturing complexes in inland provinces such as Henan to allow workers to live closer to home, and tap cheaper labor costs." 183 It also sought to limit suicides by requiring employees to pledge not to kill themselves. ${ }^{184}$ Foxconn also installed anti-suicide nets. ${ }^{185}$ But efforts were to no avail. By November 2010, two more workers had successfully committed suicide. ${ }^{186}$ Throughout the year, Foxconn insisted it had acted within the requirements of law and its own policies. However, a civil society actor, China Watch, reported on the death of another worker, suggested serious violations of Chinese law, Foxconn's CSR policies, and Apple's Supplier Code. ${ }^{187}$ Some reports traced violations

Id.

"We're trying to understand this, we have people over there," he told delegates.

181. Chinese Factory Asks For 'No Suicide' Vow, NBC NEws, May 26, 2010, available at http://www.nbcnews.com/id/37354853/ns/business-world_business/?ns=business-

world_business\#.UeiuM7y9zu4. ('I'm very concerned about this. I can't sleep every night,' said Gou, one of Taiwan's best known businessmen. 'From a scientific point of view, I'm not confident we can stop every case. But, as a responsible employer, we have to take up the responsibility of preventing as many as we can.").

182. Id. ("Foxconn was consulting with a large group of mental health professionals who have been reviewing the company's personnel records.")

183. Foxconn Worker Plunges to Death at China Plant: Report, REUTERS, Nov. 5, 2010, available at http://www.reuters.com/article/2010/11/05/us-china-foxconn-death-idUSTRE6 A41M920101105.

184. Chinese Factory Asks For 'No Suicide' Vow, supra note 182 ('Foxconn International Holdings Ltd., one of Apple's Chinese manufacturers, is asking its employees to sign a pledge that they will not kill themselves as the company tries to control the damage from a spate of suicides among its work force.").

185. See Eliot Von Buskirk, Foxconn Rallies Workers, Leaves Suicide Nets in Place (Updated), WIRED.COM, Aug. 18, 2010, available at http://www.wired.com/business/2010/ 08/foxconn-rallies-workers-installs-suicide-nets/.

186. Foxconn Worker Plunges to Death at China Plant: Report, supra note 184.

187. "According to Yan Li's family and Foxconn colleagues, because of the rapid turnaround time for many production orders, Yan Li often worked throughout the night. At one point, according to his family, Yan $\mathrm{Li}$ worked for almost 35 hours non-stop, from 7AM on May 24, to 5:47 PM on May 25. Even after leaving work on May 25, he still received calls from his superiors, making it impossible for him to rest." Another Foxconn Employee Died of Fatigue, ChINA LABOR WATCH, June 3, 2010, available at http://www. chinalaborwatch.org/pro/proshow-96.html. 
back several years before 2010. ${ }^{188}$ By the end of 2010, the employee suicides and their connection with Apple were widely reported in large circulation Western media in the United States and Europe, and tellingly, in ways that appeared to affect consumer and investor judgment about Apple. ${ }^{189}$ In its 2011 Apple Supplier Responsibility Report, ${ }^{190}$ Apple reported:

Recognizing that we would need additional expertise to help prevent further tragedies, we launched an international search for the most knowledgeable suicide prevention specialists-particularly those with experience in China-and asked them to advise Apple and Foxconn. . . . Apple then commissioned an independent review by a broader team of suicide prevention experts. This team was asked to conduct a deeper investigation into the suicides, evaluate Foxconn's response, and recommend strategies for supporting workers' mental health in the future. ${ }^{191}$

Apple pledged to "continue to work with Foxconn through the implementation of these programs, and we plan to take key learnings from this engagement to other facilities in our supply base."192 But the suicides continued, in lesser number through 2013. By the end of 2011, the media attention to Apple and the Foxconn suicides had moved from the United Kingdom to important mainstream media in the United States. Though Apple was able to deflect criticism by an important media critic for verification failures, on the program "This American

\footnotetext{
188. For prior reports, see We Are Extremely Tired, With Tremendous Pressure, A Follow-Up Investgation of FoxConn, CHINA LABOR WATCH, May 18, 2010, available at http://www.chinalaborwatch.org/pro/proshow-100.html; Foxconn Tragedy Underscores Labor Violations, Lack of Respect, CHINA LABOR WATCH, July 23, 2009, available at http://www.chinalaborwatch.org/articles/2010_05_18/20090723foxconn.php; Follow Up On Foxconn, CHINA LABOR WATCH, Aug. 28, 2008, available at http://www.chinalaborwatch. org/articles/2008_08_28/index.php.

189. See, e.g., Andrew Malone \& Richard Jones, Revealed: Inside the Chinese Suicide Sweatshop Where Workers Toil in 34-Hour Shifts to Make Your iPod, DAILY MAIL (UK), June 11, 2010, available at http://www.dailymail.co.uk/news/article-1285980/RevealedInside-Chinese-suicide-sweatshop-workers-toil-34-hour-shifts-make-

iPod.html\#ixzz2ZSXsXCmc.

190. Apple Supplier Responsibility Report 2011, APPLE INC., available at http://images. apple.com/supplierresponsibility/pdf/Apple_SR_2011_Progress_Report.pdf (last visited Aug. 17, 2013).

191. Id at 18 .

192. Id. at 19 .
} 
Life," 193 reports published in the New York Times were harder to counter. ${ }^{194}$ Apple was quick to respond, denying the charges and restating its commitment to the integrity of its regulatory system. ${ }^{195}$

Still, the global attention and the monitoring of Apple's administration of its supplier responsibility system appeared to require more than the usual responses and investigations. The systemic integrity of Apple's societally constituted governance framework had reached crisis.

\begin{abstract}
The same month the episode aired, The New York Times ran a front-page investigative series about Apple's overseas manufacturing, and there were news reports about Foxconn workers threatening group suicide in a protest over their treatment. Faced with all this scrutiny of its manufacturing practices, Apple announced that for the first time it will allow an outside third party to audit working conditions at those factories and-for the first time ever-it released a list of its suppliers. ${ }^{196}$
\end{abstract}

193. In a recent and highly publicized example, the "weekly public radio program "This American Life' said on Friday that it was retracting a critical report about Apple's suppliers in China because the storyteller, Mike Daisey, had embellished details in the narrative." See Brian Stelter, This American Life Retracts Episode on Apple's Suppliers in China, N.Y. TIMES, Mar. 16, 2012, available at http://mediadecoder.blogs.nytimes.com /2012/03/16/this-americanlife-retracts-episode-on-apples-suppliers-in-china/ ('The program's host, Ira Glass, said in a statement that Mr. Daisey 'lied' to him and to Brian Reed, a producer of the program, about details related to injured workers Mr. Daisey had described meeting at Foxconn, a factory in China where Apple products are made."). The original podcast had proven to be popular. See Charles Arthur, This American Life Withdraws Damning Apple Episode, THE GUARDIAN, Mar. 16, 2012, available at http://www.guardian.co.uk/technology/2012/mar/16/foxconn-ipad-daiseynpr-retraction.

194. See, e.g., Charles Duhigg and David Barboza, In China, Human Costs Are Built Into an iPad, N.Y. TrMES, Jan. 25, 2012, available at http://www.nytimes.com/2012/01/26/ business/ieconomy-apples-ipad-and-the-human-costs-for-workers-in-

china.html?pagewanted=all\&_r=0. ("Problems are as varied as onerous work environments and serious-sometimes deadly - safety problems. Employees work excessive overtime, in some cases seven days a week, and live in crowded dorms. Some say they stand so long that their legs swell until they can hardly walk. Under-age workers have helped build Apple's products, and the company's suppliers have improperly disposed of hazardous waste and falsified records, according to company reports and advocacy groups that, within China, are often considered reliable, independent monitors." Id.).

195. Tim Cook Responds To Foxconn Worker Abuse Report: Apple Not Turning 'Blind Eye', REUTERS, Jan. 27, 2012, available at http://www.huffingtonpost.com/2012/01/27/timcook-foxconn_n_1237341.html.

196. This American Life Withdraws Damning Apple Episode, supra note 193. 
On January 13, 2012, Apple disclosed an almost complete list of its direct suppliers for the first time and announced their new membership in the Fair Labor Association. ${ }^{197}$ This shift in policy may reflect a number of realities-the recent loss of a charismatic and famously willful executive, a capitulation to skepticism from NGOs and investors about the validity of autonomous reporting, or an actual shift of internal corporate culture. The FLA will, like any third party CSR organization, impose its own requirements and image upon Apple's supply chain, limiting its corporate autonomy. ${ }^{198}$ Despite this fact, future FLA reports will exist alongside Apple's own reporting and policy statements. 199

FLA is not the only NGO with which Apple sought to partner after 2012. Their website also explains: "We've invited the Institute of Public and Environmental Affairs (IPE) and other environmental groups to work with us on specialized audits. We're also continuing our work with Verité, a non-governmental organization (NGO) focused on ensuring fair working conditions, to develop new strategies for worker-management communication." 200 These enterprises are retained for the same legitimacy enhancing function as $\mathrm{FLA}^{201}$-they assure outsiders,

197. Stanley James \& Adam Satariano, Apple Opens Suppliers' Doors to Labor Group After Foxconn Worker Suicides, BLOOMBERG (Jan. 13, 2012, 4:54 PM), http://www.bloom berg.com/news/2012-01-13/apple-opens-suppliers-doors-to-labor-group-after-foxconn-

worker-suicides.html. The FLA Press Release noted: "that Apple will join the FLA as a Participating Company, effective immediately. The FLA will independently assess facilities in Apple's supply chain and report detailed findings on the FLA website." Apple Joins FLA, FLA, Jan. 14, 2012, available at http://www.fairlabor.org/blog/entry/applejoins-fla.

198. Apple Joins FLA, supra note 197. ("FLA Participating Companies agree to uphold the FLA Workplace Code of Conduct throughout their supply chains and commit to the FLA's Principles of Fair Labor and Responsible Sourcing.").

199. Thus, Apple continues its practice of producing Supplier Responsibility Progress Reports grounded on its own autonomous Supplier Conduct Code, while the Fair Labor Association simultaneously generates reports of its monitoring activities of Apple that are based on its own third-party standards.

200. 2013 Supplier Responsibility Progress Report, Our Commitment to Transparency, APPLE, INC., available at http://www.apple.com/supplierresponsibility/reports.html (last visited Sept. 15, 2013).

201. The importance of the legitimacy-enhancing function of the Apple regulatory system is highlighted in the 2013 Apple Supplier Responsibility Progress Report:

To hold ourselves accountable, we reference a variety of external sources including the IPE pollution database, which highlights suppliers with environmental citations by local regulatory agencies in China. This is an additional resource to assess the risk of our suppliers and target our focused environmental audits. In 2012, we completed 55 focused environmental audits-a 293 percent increase over 2011. Of the 55 sites, 26 were cited in the IPE database.

Apple Supplier Responsibility 2013 Report, APPLE, INC., at 27, available at http://images. apple.com/supplierresponsibility/pdf/Apple_SR_2013_Progress_Report.pdf (last visited Sept. 15, 2013). 
principally consumers and investors, of the integrity of Apple's efforts at enforcing its own regulatory structures and thus at strengthening at the operational level, the cohesion of its control. ${ }^{202}$ At the same time, these couplings also require Apple to bend its regulatory structures to conform, at least to some extent, with the standards of the third-party certification entities.

Thus, although Apple was able to use the weight of its CSR policies to limit the consequences of early scandals, ${ }^{203}$ crisis produced substantial change that both produced a more permeable societally-constituted governance system, but also one that retained its internal coherence. However, the lasting effects of seemingly unrelenting publicity from 2010 forward and the attention by mass media and third party groups demonstrated that the legitimacy issues that faced Apple also would be felt, in almost equal measure, by third party certification partners, who themselves have become subject to scrutiny. ${ }^{204}$ At present, the company's previous reliance on autonomous reporting practices may have had the long-term effect of reducing its ability to manage its broader corporate image autonomously of the systems with which it is intermeshed. But that price has purchased coherence and preserved system integrity. Independent reporting practices can appear to provide a company with an appealing set of central and secondary advantages, but they do not reflect the realities of system operations embedded in a world of intermeshed systems that must satisfy the desires of multiple audiences or respond rapidly to optics problems when something goes wrong.

Thus, crisis, and the possibility of catastrophe (in the form of the attacks on the integrity of Apple's societally-constituted supply chain governance structures) moved Apple from a self-contained system with fairly limited structural coupling, to one in which its constituted

202. The 2013 Supplier Responsibility Progress Report explains:

We look for environmental issues at many supplier levels, often confronting serious issues deep within our supply chain. But we know that risks are not the same for all suppliers. So we target high-risk suppliers for an additional layer of scrutiny with our focused environmental audits, and we work with them to lessen their impacts. To ensure our standards and our approach reflect material environmental issues, we work with independent organizations such as the Natural Resources Defense Council (NRDC), the Environmental Protection Agency (EPA), and the Institute of Public and Id. at 27.

Environmental Affairs (IPE).

203. Larry Catá Backer, Apple, Inc, the FLA and the Governance of Supplier Labor Standards Beyond the State, Law at the End of the Day, Jan. 17, 2012, available at http://lcbackerblog.blogspot.com/2012/01/apple-inc-fla-and-governance-of.html.

204. Steven Greenhouse, Critics Question Record of Monitor Selected by Apple, N.Y. TIMES, Feb. 14, 2012, at B1. 
structures are now intermeshed with those of its suppliers (Foxconn's CSR policy structures), with externally constituted standard-making and monitoring organisms, while remaining connected with the regulatory systems of the states in which they operate and the international standard setting bodies form which they continue to draw their own norms. Apple's regulatory structures are now more porous and flexible within a polycentric context in which its governance is one of several simultaneously operative layers all in dynamic flux. We move here from two-dimensional to three-dimensional simultaneous cyclidity.

\section{B. Systemic Stress and Resilience: A First Level Analysis}

Apple's response to crisis and the resilience of its regulatory system exhibit all of the elements of self-constitution, and of the intermeshing whose presence is best exposed under conditions of catastrophic stress. Apple's constitutional system is both self-referencing and autonomy enhancing. It sits in a space other than that occupied by states or other governance organizations. Yet, it is also wholly enmeshed in systems of communication (structurally coupled) of other governance organs where its "territory" overlaps. The effects of that communication on Apple's internal rulemaking, and the effect of these inward projects on outward solidification of legitimacy of the Apple structure were well illustrated in the Foxconn crisis.

The result is interesting in several respects. First, it suggests the growing markets for CSR governance. Second, it also illustrates the increasingly important role of NGOs in the development of standards and their monitoring and enforcement-functions once thought central to the role of states. Third, it evidences the economics of CSR enforcement, at least in some areas. Apple became an accredited enterprise within the FLA family because it made economic sense to do so-that indicates both the lower costs of FLA overseeing compliance and the benefits of belonging to a wider group of enterprises and NGOs that have developed and are adhering to common social norm (soft law voluntary) standards.

The first decade of the twenty-first century has seen a dramatic growth in the depth and sophistication of governance systems beyond law that focus on the regulation of the labor policy of downstream enterprises in multinational supply chains. ${ }^{205}$ One of the markers of

205. "Such [employer generated] instruments establish private contract-like mechanisms for monitoring and enforcing compliance with international labor standards, obligating multinational corporations and sometimes also other private businesses within the multinational's supply chain." Marley S. Weiss, International Labor and Employment Law: From Periphery to Core, 25 ABA J. LAB. \& EMP. L. 487, 500-01 (2010). "Generally, 
that growth is the rise of enterprises, the objects of which are to both develop normative governance frameworks and provide a space for monitoring compliance. ${ }^{206}$ Many of these monitoring mechanisms are product or process certification programs managed by civil society elements. 207

Related to product certification programs, these standards evaluators have become powerful mechanisms to enforce the private ordering governance derived from the adoption of voluntary codes of behavior by multinational enterprises. "In the not-for-profit field both accreditation and certification have been undertaken by self-regulatory organizations, which have promulgated standards and developed certification or accreditation mechanisms to evaluate compliance by other organizations with the standards."208 Beyond product certification, process certification has provided NGOs with a new and more institutionalized role in the application of governance standards among communities of enterprises that have adopted them. ${ }^{209}$

Organizations like FLA institutionalize transparency mechanisms so that markets for information and disclosure can arise-producing

reference to supply chains in CSR reports is on the increase, although it was found that approximately half of the major multinationals omit reference to their suppliers." Guy Mundlak \& Issi Rosen-Zvi, Signaling Virtue? A Comparison Of Corporate Codes In The Fields Of Labor And Environment, 12 THEORETICAL INQUIRIES L. 603, 626 n.46 (2011). Supply chain management in the context of corporate social responsibility generally, and the human rights effects of business activity specifically, has become the subject of important soft law regulatory structures. See, e.g., OECD Guidelines, supra note 97; Special Representative of the Secretary-General on the Issue of Human Rights \& Transnational Corps. \& Other Bus. Enters., Guiding Principles on Business and Human Rights: Implementing the United Nations "Protect, Respect and Remedy" Framework, Human Rights Council, U.N. Doc. A/HRC/17/31 (Mar. 21, 2011) (by John Ruggie), available at http://www.business-humanrights.org/media/documents/ruggie/ruggieguiding-principles-21-mar-2011.pdf.

206. See, e.g., Errol E. Meidinger, The New Environmental Law: Forest Certification, 10 BUFFALO ENVTL. L.J. 213 (2001). This has been criticized as permitting what is now called "greenwashing"- the use of third party certification organizations to cover standards violations by large enterprises. See, e.g., Jacob Vos, Note, Actions Speak Louder than Words: Greenwashing in Corporate America, 23 NotRe DAME J.L. ETHICS \& PUB. POL'Y 673 (2009).

207. See, e.g., Fabrice Etilé \& Sabrina Teyssier, Signaling Corporate Social Responsibility: Third-Party Certification vs. Brands, ALISS Working Paper 2012-06 (Sept. 2012). See also Backer, supra note 203.

208. Catherine Shea \& Sandra Sitar, InT’l CTr. For Not-For-Profit Law, NGO

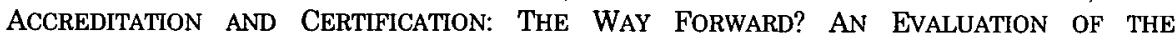
DEVELOPMENT COMMUNITY'S EXPERIENCE 7 (2005), available at http://pdf.usaid.gov/pdf docs/PNADB766.pdf. The standards are frequently developed through a participatory process in which many stakeholders are consulted.

209. See generally Janet Dine, Democratization: The Contribution of Fair Trade and Ethical Trading Movements, 15 IND. J. GLOBAL LEGAL STUD. 177 (2008). 
similar disclosure products for consumption by investors and consumers to guide their purchase and investment decisions. ${ }^{210}$ This system provides a viable approach to transnational governance without the need for states. Effectively, FLA contributes to making soft law functionally hard while it retains its character, within public law frameworks, as soft. ${ }^{211}$ While accredited companies lose autonomy in the construction and application of voluntary codes throughout their supply chain, they gain a certain legitimacy by adhering to the collaborative standard-setting and transparency-facilitating outside institutions. Accredited companies can outsource enforcement while retaining a substantial stake in the development of both the standards to be applied and the monitoring systems applied. The dynamics of these developments is nicely illustrated with the ongoing difficulties at the Foxconn plants in China, a facility operated by multinational interest for the purpose of supplying parts and other goods to multinational enterprises in the production of a host of consumer products for sale worldwide. ${ }^{212}$

Most important, though, the crisis and its management suggests the ways in which institutions may structurally couple in a variety of ways to preserve a space for regulatory autonomy especially potent in a polycentric governance framework. The consequence is that though third-party standard setting and their function of monitoring and

210. See Accreditation, FAIR LAB. ASS'N, http://www.fairlabor.org/accreditation (last visited Apr. 8, 2013). The Fair Wear Foundation nicely illustrates this relationship:

Companies that produce and distribute products of which the main manufacturing process is sewing can join FWF and, depending on the direct influence they have with garment factories, become an FWF affiliate or FWF ambassador. Both affiliates and ambassadors of FWF work towards improving the labour conditions in factories and workshops where the 'cut-make-trim' stage takes place, all over the world. The basis of the collaboration between FWF and a member is the Code of Labour Practices. Eight labour standards form the core of the Code of Labour Practices. Members of FWF must comply with this Code of Labour Practices.

About, FAIR WEAR FOUNDATION, available at http://www.fairwear.org/22/about/. The FWF Code of Labour Practices is based on international normative standards, none of which mind states as a matter of international or domestic law-the Universal Declaration of Human Rights and the חLO Convention. See FWF Code of Labour Practices, at 1, available at http://www.fairwear. org/ul/cms/fck-uploaded/documents/companies/FWFdocs/fwfcodeoflabour practices.pdf (last visited Sept. 15, 2013).

211. See generally Larry Catá Backer, From Moral Obligation to International Law: Disclosure Systems, Markets and the Regulation of Multinational Corporations, 39 GEO. J. INT'L L. 101 (2008).

212. See Larry Catá Backer, Corporate Governance and the Social License to Operate: Foxconn and the Limits of Legal Formalism in Corporate Governance, LAW AT THE END OF THE DAY (June 8, 2010), http://lcbackerblog.blogspot.com/2010/06/corporate-governanceand-social-license.html. One of the consumers of Foxconn products is Apple, Inc. 
process certification is potent, the ability of organizations like FLA to bring other autonomous governance actors within their orbit remain limited. The relationship between Apple and FLA strengthened their respective governance autonomy structures but did not cause one to be absorbed into the other. Even as an FLA accredited company, Apple still retains control over its supplier governance systems in the areas beyond labor standards-significantly these include the areas of environmental standards, ethics, management systems, and worker education rules. The result is the continued elaboration of hybrid governance systems, even in the purely private sphere. And make no mistake, Apple has elaborated a complex and deep system of governance. Its engine is legislation in the form of contract and practice-the supplier code of conduct. 213

It is regulatory in function, providing Apple with a substantial authority not merely to monitor compliance, but also to train and socialize the members of suppliers. Apple's enforcement is dependent on its ability to report its activities to its principal constituents-shareholders and consumers. The conduct standards are thus directed toward investor and consumer taste and not necessarily dependent on the needs or desires of the objects of the codes. But they were also directed inward through the supply chain and downward from Foxconn to its own suppliers. One of the most interesting aspects of the communication among Apple and Foxconn was evidenced by the replication of Apple's vertically arranged governance structures by Foxconn with respect to its own suppliers. In its 2011 CSR Report, Foxconn described its own "Supplier SER management" in terms that mirrored those applicable to it through the Apple Supplier Code of Conduct. 214 This included a zero tolerance policy covering six identified areas, ${ }^{215}$ the requirement that all suppliers enter into environmental protection contracts with Foxconn, ${ }^{216}$ conform their conduct to Foxconn's

213. Apple Supplier code of conduct, page 1 provides:

Apple requires that Suppliers implement this Code using the management systems described below. Apple may visit (and/or have external monitors visit) Supplier facilities, with or without notice, to assess compliance with this Code and to audit Supplier's wage, hour, payroll, and other worker records and practices. Violations of this Code may result in immediate termination as an Apple Supplier and in legal action.

Apple Supplier Code of Conduct, supra note 140, at 1.

214. 2011 CSER Annual Report, FoxCONN, at $42-46$, available at http://ser.foxconn.com/ SelectLanguageAction.do?language $=1 \& j u m p=/ \operatorname{cser} /$ Annual_Report.jsp (last visited Sept. $15,2013)$.

215. Id. at Section 6.1 (child labor, prison labor, hazardous waste, working conditions, falsification of information, and employee retaliation).

216. Id. at Section 6.2. 
conflict minerals management policies, ${ }^{217}$ and participate in Foxconn's programs of combatting global warming. ${ }^{218}$ While these existed autonomously of those of Apple (and applied to all of Foxconn's operations, including those for enterprises other than Apple) throughout its own global supply chain, it tended to be operated in constant dialogue with Apple's own system and those of other multinationals with which Foxconn engaged in business. That both Apple and Foxconn operated regulatory regimes on Foxconn's workers (at least those assigned to Foxconn's Apple operations) provides a good illustration of polycentric governance at the heart of globalization governance. ${ }^{219}$ And it might follow that Foxconn's own CSR regulatory structures might exhibit characteristics similar to those of Apple, though exhibited independently of Apple's.

The content of Apple's CSR documentation, coupled with the responses and criticism it has garnered since its publication, provides a fruitful means of examining the effectiveness of autonomous, self-managed CSR practices. Apple compliance materials, primarily the "Supplier Responsibility Progress Reports," for the years 2006-2012, were retrieved from the Apple website. 220 It should be no surprise that publicly available reporting material provided by Apple is primarily aimed at assuring investors and public critics that the company is doing everything it can to live up to the aspirations of its broadest policy statements. Apple presents a patchwork of interconnected, disjointed, and occasionally out-of-date HTML and PDF documents, making the task of locating specific information about the company's current policies in CSR practices a difficult task. For example, each Apple product's energy efficiency is recorded in a separate PDF file, making direct comparisons difficult. The layout of the website is divided

217. Id. at Section 6.3. This program was, in turn, coupled with emerging international standards on conflict minerals management that reflected both developments in public international law, in the norms produced by public international organizations, and in the standards developed by the private certification and standard-setting organizations with which Foxconn engaged. But that engagement did not diminish the coherence of Foxconn's own self-constituted CSER regulatory framework. The resulting governance universe evidences its three dimensional spatial qualities. See discussion, infra, Section III.

218. Id. at Section 6.4.

219. This is what Gunther Teubner references as polycentric globalization. See Gunther Teubner, The Corporate Codes of Multinationals: Company Constitutions Beyond Corporate Governance and Co-Determination, in CONFLICT OF LAWS AND LAWS OF

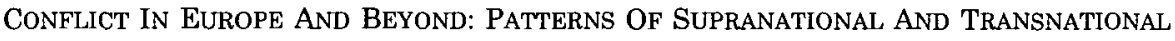
JURIDIFICATION (Rainer Nickel, ed,, 2009).

220. Apple Supplier Responsibility Progress Report, APPLE.COM, http://www.apple.com/ supplierresponsibility/reports.html (last visited Apr. 8, 2013) (listing all reports from 2007 to 2013). The 2006 Progress Report is no longer available publicly. Reports may be obtained in the Historical Reports section. 
between environmental concerns in one division and supplier activities in the other, absent any unified organization. This leads to the presence of outdated and sometimes conflicting information. For example, the Environmental FAQs page directs users interested in Apple's Global Reporting Initiative (GRI) compliance on unspecified environmental indexes to the 2009 Facilities Report. 221 An "Environmental Update" reached from the main environmental reporting page is actually a letter to consumers from Steve Jobs, dating back to 2008.222 A concerned member of the public may easily leave the site with old information or with the belief that the information is unavailable when it may in fact be hidden in a PDF file that has been cut off from the site architecture by a long-past update. The chaos of Apple's CSR aesthetics is all the more jarring given the company's reputation for clean and effective, easy-to-navigate design.

The messiness of Apple's communication makes sense, however, when it is understood not as an attempt to comply with externally developed regulatory norms, but as an attempt by the company to avoid being tethered to an externally determined set of information practices. Apple exemplifies the corporate actor for whom transparency has historically held little appeal, particularly the norm exposure that would come from third party frameworks. Enjoying a secure market position and high market power control over its manufacturing supply chain, disclosure of factory conditions offers little benefit to the company in the absence of public outcry or criticism. In response to early concerns about environmental effects, Apple captured a valuable opportunity-its captive consumer audience and high level of trust allowed self-reporting to reflect an intrinsically reliable extension of the Apple brand, effectively annulling its need to enter the market of reporting standards. For a period, Apple's own statements effectively competed with others applied to the company by critical media and NGO parties. These tended to mitigate negative social perceptions while simultaneously buttressing Apple's legitimacy as a CSR practitioner among consumers made newly aware of the environmental and labor costs of its business.223 Apple was able to "double down" on its preexisting corporate image by presenting its own information, while

221. Apple and the Environment: Frequently Asked Questions, APPLE (Feb. 28, 2012), http://web.archive.org/web/20110224013423/http://www.apple.com/environment/faq.html (archival copy of the current environmental frequently asked questions page).

222. Apple 2008 Environmental Update, APPLE, http://www.apple.com/environment/re ports/update.html (last visited Apr. 8, 2013).

223. It is, for example, notable that Apple has been careful to include its supplier responsibility and environmental reporting in its "Investor News" section. See Investor News, APPLE, INC., available at http://investor.apple.com/ (last visited Sept. 15, 2013). 
gaining time to work behind the scenes to discipline and manage the consequences of unpopular supplier practices. International corporations are frequently able to maintain effective private CSR standards for an extended period and can use them to leverage and enforce changes in industrial practice, effectively competing with watchdogs and third party monitors to define the scope of legitimate corporate action, while leveraging them to other market effects. ${ }^{224}$ Companies occupying this state of dominance can also dictate the practices of their suppliers and competitors by altering the scope of acceptable corporate behavior. ${ }^{225}$ At a minimum, companies facing criticism can use the competing policies of their CSR governance to blunt and control the scope of public criticism. ${ }^{226}$ This is a process that may continue as Apple gradually shifts to reporting governed by or in compliance with third party practices.

Thus, in attempting to develop its disclosure practices as criticism occurred, Apple produced a CSR regime that could not truly satisfy its critics. This contributed to the crisis of legitimacy and the viability of its societally constituted governance structures. The way in which Apple communicated its enforcement of its own regulatory system provides a window on the nature of the failures leading to crisis. ${ }^{227}$ At multiple places within the design and text in its reporting documents, the struggle between relying upon the formulae of other CSR entities and constructing a special, Apple-specific transparency philosophy is apparent. The authors of Apple's reporting policies and products are clearly aware of independent standards, and take pains to both

224. Again, Walmart is a pioneering example of this practice in both good and bad supplier practices. See, e.g., Xiaomin \& Ngai, supra note 157, at 63-70.

225. See Larry Catá Backer, On the Autonomous Regulatory Authority of Corporations in Global Private Markets: Governance Between Corporation and State, LAW AT THE END OF THE DAY (Mar. 28, 2011, 9:13 PM), http://lcbackerblog.blogspot.com/2011/03/ontheautonomous-regulatory-authority.html.

226. See Larry Catá Backer, Corporate Social Responsibility and Voluntary Codes: Apple, Its Stakeholders and Its Chinese Laborers, LAW AT THE END OF THE DAY (June 16, 2006, 5:50 AM), http://lcbackerblog.blogspot.com/2006/06/corporate-social-responsibility-and.html.

227. Communication in this case suggests a multi-dimensional loose structural coupling between institution and stakeholder that combines to create a dynamic environment in which legitimacy, loyalty, and interactions with the system among its shareholders is of central concern. "A loosely coupled system is a good vehicle for registering objectives outside of itself, but is itself an elusive object to understand. Thus, in a loosely coupled system, what is most likely to be socially constructed is the system itself, not the world it faces." J. Douglas Orton \& Karl E. Weick, Loosely Coupled Systems: A Reconceptualization, 15(2) THE ACADEMY OF MANAGEMENT REVIEW 203-23, 218 (1990), available at http://xa.yimg.com/kq/groups/19459303 /1351724291/name/OrtonWeick1990LooselyCoupledSystems.pdf ("Loose coupling, for example, is the product of many years of effort by organization theorists to combine the contradictory concepts of connection and autonomy." Id. at 216). 
acknowledge their existence and evade their use. For example, the clearest mention of GRI compliance, the only listing of indices which Apple claims to report, is found under the environmental website. ${ }^{228}$ This webpage includes links under headings such as "Governance" and "Supplier Responsibility," but these links lead to other front pages on the Apple home page without the actual GRI-compliant information. The 2011 Facilities Report includes the statement that GRI guidelines "were considered during the preparation of this report," and specific indices are referenced as "applicable" in footnotes at the end of different sections. ${ }^{229}$ In the partitioned area of Apple's public site devoted to supplier practices, the most heavily promoted transparency document is the Supplier Code of Conduct, which acts as an overarching statement of policy, guiding the content of other representations made by the company regarding its stakeholder impacts. ${ }^{230}$ The Code of Conduct emphasizes that it "is modeled on and contains language from" a number of international and private standards. ${ }^{231}$ At the same time, although there are many commonalities of language, no single document or set of norms is used as the basis for Apple's policies, a fact which becomes even more confusing when the annual progress report is consulted. Each year's report applies similar aspirational language, but appears to hold the company to a different standard of disclosure. This issue is partially addressed in the Supplier Responsibility 2012 Progress Report, in which the detail and number of supplier site audits is greatly increased.232 The report represented an implicit concession by Apple that previous reports were inadequate, while ensuring that the company would continue to manage the perception that future revelations about its supplier chain were viewed in a context influenced by Apple's behavioral ethos.

As with other companies that approach participation with large-scale transparency efforts in this way, third party entities have investigated Apple's business practices, in particular employment and environmental practices at locations along the manufacturer's supply chain. Representative of these investigative efforts is the report published in 2007 by the Stichting Onderzoek Multinationale Ondernemingen (SOMO), a nonprofit organization whose activities are

228. Apple and the Environment: GRI Index, APPLE.COM, http://www.apple.com/environ ment/reports/gri-index.html (last visited Apr. 8, 2013).

229. See Apple, Inc. 2011 Facilities Report: Environmental Update, APPLE.COM, at 1, available $a t$ https://www.apple.com/environment/reports/docs/Apple_Facilities_Report_20 11.pdf.

230. Apple Supplier Code of Conduct, supra note 140.

231. Id. at 1, 7-8.

232. Apple Supplier Responsibility 2012 Progress Report, APPLE (Jan. 2012), http:// images.apple.com/supplierresponsibility/pdf/Apple_SR_2012_Progress_Report.pdf. 
funded in part by the Dutch government and which organizes and interacts with other environmental and labor-oriented corporate transparency organizations. ${ }^{233}$ It "investigates multinational corporations and the consequences of their activities for people and the environment around the world." 234 By aggregating Apple's CSR policy statements and other public disclosures, then comparing them with employee interviews at several supplier factories around the globe, SOMO attempted to see how well the company was living up to the aspirational language of its policy claims. ${ }^{235}$ As might be expected, a wide gap existed between Apple's stated policy and its on-the-ground practices. ${ }^{236}$ This and other reports by private and media entities have publicized the obscurity and potential for abuse latent in Apple's self-regulated supply system. The environmental NGO "As You Sow" has been one major source of internal pressure for the corporation, having introduced multiple shareholder proposals designed to gradually move the corporation toward greater public disclosure on its environmental impacts, including proposals for Apple to join more conventional reporting structures. ${ }^{237}$ Although Apple has occasionally acquiesced to limited additional disclosure, it has only recently agreed to broader cooperation with third party entities. Beyond the stated purpose of maintaining its privacy and the advantage of a secret supply system, Apple has clear incentives to avoid structural entanglement; investment companies have used UNGC standards as a basis for excluding companies with controversial business practices from their portfolios. ${ }^{238}$

But these outside monitors also encounter difficulties and are themselves sometimes subject to the disciplines of transparency. Control of data by the data generator, in this case Apple, makes it far more difficult to verify and contest the information produced. The transaction costs of data verification can be substantial and the process

233. See Ctr. for Research on Multinational Corps., About SOMO, SOMO, http://somo. nl/about-somo (last visited Apr. 8, 2013).

234. Id.

235. Michiel vaN DiJK \& IRENE Schipper, APPle CSR Company Profile 4 (2007), available at http://somo.nl/publications-en/Publication_1963.

236. Id. at 44.

237. Climate: Corporate Reporting and Emission Reduction in Computer/IT Sector: Apple, As You Sow, http://asyousow.org/sustainability/climate\%20IT\%20apple.shtml (last visited Apr. 8, 2013).

238. See, e.g., Desiree Kopppes, Delta Lloyd Excludes 38 Companies for Violating Global Compact Principles, GLOBAL COMPACT CRITICS (Feb. 2, 2012), http://globalcompactcritics. blogspot.com/2012/02/delta-lloyd-excludes-38-companies-for.html. 
difficult. ${ }^{239}$ In a recent and highly publicized example, the "weekly public radio program 'This American Life' said on Friday that it was retracting a critical report about Apple's suppliers in China because the storyteller, Mike Daisey, had embellished details in the narrative."240 A correspondent for another radio program discovered the errors. ${ }^{241}$ This correspondent tracked down the interpreter Daisey hired who disputed what Daisey said on his show. ${ }^{242}$ Apple had been reported as having attempted unsuccessfully to rebut the allegations for some time before. ${ }^{243}$ Ironically this may as well suggest that, like markets for transparency structures, third party and civil society monitors may also be disciplined by competitive forces within the constraints of their own ethics universe. It also suggests the problems of monitoring transparency in the context of the purpose for which it is used-reporting, remediation, correction, or participation in decisions about the continued engagement in certain activity. In this case, the misrepresentations were actually of events that had occurred, and had been reported, but not in the context in which they were then used. ${ }^{244}$

239. See generally Larry Catá Backer, Economic Globalization and the Rise of Efficient Systems of Global Private Law Making: Wal-Mart as Global Legislator, 39 CoNN. L. REV. 1739 (2007) (analyzing the cost of monitoring as an aspect of private legislation through global supply-chain management contracts).

240. Stelter, supra note 193.

241. Id. From the This American Life Retraction, a description of the magnitude and scope of the errors:

Some of the falsehoods found in Daisey's monologue are small ones: the number of factories Daisey visited in China, for instance, and the number of workers he spoke with. Others are large. In his monologue he claims to have met a group of workers who were poisoned on an iPhone assembly line by a chemical called n-hexane. Apple's audits of its suppliers show that an incident like this occurred in a factory in China, but the factory wasn't located in Shenzhen, where Daisey visited.

Press Release, This Am. Life, This American Life Retracts Story: Says It Can't Vouch for the Truth of Mike Daisey's Monologue about Apple in China (Mar. 16, 2012, 1:00 PM), available at http://www.chicagopublicmedia.org/sites/default/files/Retraction\%20Press\%20 Release\%20Final.pdf.

242. Ira Glass, Retracting "Mr. Daisey and the Apple Factory," THIS AM. LIFE (Mar. 16, 2012), http://www.thisamericanlife.org/blog/2012/03/retracting-mr-daisey-and-the-applefactory.

243. Paul Farhi, 'This American Life' Cites 'Fabrications' in Documentary on Apple Suppliers, WASH. POST (Mar. 16, 2012), http://articles.washingtonpost.com/2012-03-16/life style/35450242_1_mike-daisey-gorgeous-devices-factory-accident.

244. The news story about the retraction also noted:

In a report for "Marketplace" on Friday, Mr. Schmitz acknowledged that other people actually had witnessed harsh conditions at the factories that supplied Apple. "What makes this a little complicated," he said, "is that the things Daisey lied about are things that have actually happened in China: Workers making Apple products have been poisoned by hexane. Apple's own audits show the company has 
As a consequence, the reporting might have been misleading, but the purpose-to deploy information to pressure a reporting entity to abandon a particular practice or work place rule in favor of others-was based on something approaching verifiable facts.

Yet, communication with shareholders and consumers, both direct and indirect, remained essential. In that respect, global media sources play a critical role. Recall the critical role of the press in reporting the suicides, Apple's reactions, and the studies by various NGO's and in facilitating the transmission of witness testimonials to consumers and investors in Western states that would have provided the impetus toward Apple's regulatory joint venture with FLA.245 NGOs play a critical role as authenticators, monitors, and standards stakeholders. Their participation ensures a certain legitimacy in the system and also makes it harder for enterprises to use the system solely for self-serving purposes. Together, these participants have built a system that is internally consistent and coherent, but is fundamentally fluid and dynamic. The system draws on, but does not depend on, the action of states and other international public bodies. Like others systems, it is imperfect, and subject to manipulation and abuse, but at least to some appreciable extent, it also appears to work without the direct intervention of states. The societal constitution of Apple, Inc. is heavily embedded within networks of regulatory systems developed and operated by national and international public and private bodies, whose standards may be invoked by stakeholders with allegiances across multiple regulatory planes by actors that mediate systemic communication and enhance the effects of that communication in terms of facilitating information flows. Apple's interactions with its stakeholders trigger both legitimacy issues with respect to its ability to enforce its own regulatory system, and integrity issues as stakeholders seek to apply multiple standards simultaneously to events that trigger regulatory response. Something as simple (though horrific and tragic on a personal level) as employee dissatisfaction marked by extreme action-suicide-may trigger complex structural coupling among interpenetrating systems whose actions serve as both evolutive responses to this stimulus and actions to preserve the integrity of societally constituted organisms. Apple continues to thrive as an autonomous regulatory, even as it operates within a number of states with distinct legal systems and among public and private international

caught underage workers at a handful of its suppliers. These things are rare, but together, they form an easy-to-understand narrative about Apple."

Stelter, supra note 140.

245. See generally Backer, supra note 203. 
organizations with applicable regulatory frameworks of their own. The last section takes up the theoretical implications of this reality.

\section{STABLE CONSTITUTIONS In DYNAMic OSCILLATION AND COLLISION COURSE}

The story of Apple, Inc.'s regulatory relationships with its downstream Chinese supply chain illustrates a dynamic element to societal constitutionalism. The discussion of constitutionalism, of course, freezes and crops a moment in time and an organization or organizational type, but organizations exist both in time and among other organizations-organizations both similar and dissimilar within the constitutionalizing logic of globalization. Moreover, organizations, whether states or nonstate actors, exist not merely in time, but also in constant collision with each other. What in Section I appeared as little more than the theoretical expansion of the family of self-constituted actors becomes, in Section II a functionally dynamic polycentric mass that not just communicates but collides, conflicts, and affects the external extent of governance spaces and the internal organization of those spaces. Constitutionalism, then, requires a consideration of autonomy, form, and function within a crowded field of distinct actors that must develop a method of both receiving action from outside the self-constituted society and internalizing this communication naturalized through the framework of the rules by which a society has constituted itself. ${ }^{246}$ It requires a language for that purpose. ${ }^{247}$ Is it possible to extract premises of the dynamic element of societal constitutions?

Hans Lindahl has mapped out a topology of legal orders in a global setting with constitutionalist implications. ${ }^{248}$ That topology posits a set of interlocking propositions that describe the basic spatial structure of governance orders. The first proposition is that legal orders create normative points that permit borders, differentiating and integrating a

246. This, of course, is the essence of the problem facing Apple in its dynamic confrontation with a crisis of legitimacy and systemic coherence within a polycentric governance universe. See discussion, Section II.A., supra.

247. Poul F. Kjaer, Transnational Normative Orders: The Constitutionalism of Intraand Trans-Normative Law, 20 IND. J. GLOBAL LEGAL STUD. 777 (2013) ("[A] broader category of law, which deals with transfers and adaptation between normative orders as such, has emerged. This type of law can also be understood as a specific form of transnormative law insofar as it is characterized by a relative structural supremacy of cognitive rather than normative structures of expectations due to its primary orientation towards the establishment of increased mutual adaptability between normative orders.").

248. See Lindahl, supra note 59. 
governance space into a unity within the space (ought places) ${ }^{249}$ that is the point of regulation. The second proposition is that this special unity creates a border, much like the physical borders of the territorial frontiers of states. 250 The third proposition is that this closing of frontiers permits ownership of the space enclosed, and thus its control as against outsiders. ${ }^{251}$ The fourth proposition is that, so allocated, the notion of space becomes ambiguous-a space is always both inside and outside depending on the perspective of the observer. ${ }^{252}$ The fifth proposition is that these ought places themselves may produce strange places that fall outside a collective's own space. ${ }^{253}$ The sixth proposition is that the inside-outside distinction is irreducible to each other, "a strange place need not be foreign; a foreign place need not be strange."254 The seventh proposition, that distinctions among spaces are fundamentally contingent, is made manifest by space and rule (spatial and legal orders). ${ }^{255}$ The result, illustrated through the development of modern cyberlaw, ${ }^{256}$ suggests both the emergence of polycentric orders and their intermeshing along multi-spatial and legal ordering lines.

Lindahl's analysis adds a third dimension to the conventional two-dimensional conceptualization of governance space in the wake of globalization. ${ }^{257}$ Poul Kjaer speaks of a "common feature of public and private organizations operating in the transnational space is that they-despite numerous predictions of the opposite-internally tend to have a vertical nucleus in the form of a hierarchical organizational structure of the sort originally described by Weber." 258 As a consequence, it is common to understand a crowded two-dimensional space-organized by territory-within which a host of functionally differentiated self-reflexive and constituted governance units can operate simultaneously.

249. "Ought places" are understood as "places where behavior ought or ought not to take place-that lends a spatial form to the common interest of a community." Hans Lindahl, A-Legality: Postnationalism and the Question of Legal Boundaries, in GLOBAL DEMOCRACY AND EXCLUSION 117, 123 (Ronald Tinnevelt \& Helder De Schutter, eds., 2010).

250. See Lindahl, supra note 59.

251. Id.

252. Id.

253. Id.

254. Id. at 722 .

255. Id.

256. $I d$.

257. See generally Poul F. Kjaer, The Metamorphosis of the Functional Synthesis: A Continental European Perspective on Governance, Law, and the Political in the Transnational Space, 2010 WIS. L. REV. 489.

258. Id. at 505 . 
The consequence is that a multitude of different forms of normative orders can be observed in the transnational space. A highly complex disorder of normative order exists in the sense that a whole range of structures producing their own forms of normativity operates and collides like billiard balls in the transnational space. Especially small and mid-sized states are therefore reduced to one set of actors among many. ${ }^{259}$

But Lindahl suggests another layer to societally constituted governance units. He suggests instead, not merely fracture, ${ }^{260}$ but porosity. Functional differentiation in the constitution of systems produces governance units that are not fortresses with impermeable borders that can be physically felt. Rather, space is understood as divided two-dimensionally (horizontally and vertically)-the way fracture and the functional differentiation within a territory is understood-and also spatially-self-constituted systems may reach the same set of actors (objects and subjects of regulation) simultaneously, the way polycentricity is understood. ${ }^{261}$ But spatiality is also understood in changes to the quality of the border and hence the constitutional character of permeability. ${ }^{262}$ The resulting dynamic, triggered by the activities of these subjects and objects or regulation, produces a dynamic element to the constitution of systems that itself then reaches back into each closed system, producing a constitutional effect through a cycle of action and response that touches on the constitutional boundaries of a governance system. ${ }^{263}$

259. Id. at 507 .

260. Id.

261. Id.

262. This was nicely suggested in Saskia Sassen, Bordering Capabilities Versus Borders: Implications for National Borders, 30 MICH. J. INT'L L. 567, 569 (2009) ("The new specialized borderings that I describe are the borders of our current age: they cut across traditional borders but do not necessarily reduce the incidence of borders, even though they change the character and logics of bordering."). It is also suggested in Gunther Teubner's work on the modalities of contract. Gunther Teubner, In the Blind Spot: The Hybridization of Contracting, 8 THEORETICAL INQUIRIES L. 51, 55-56 (2007) ("Our first interim finding is that social differentiation splits the formerly unitary contract into three autonomous concatenations of events in the respective legal, economic, and production contexts. This difference is-despite (or even because of) mutual observation, structural coupling, re-entry, and co-evolution-always reproduced anew as an insurmountable hermeneutic dissonance.").

263. It is in this sense, perhaps that one can understand how, for example, nonstate actors may act as steering subjects in international economic law while being steered. See, e.g., Karsten Nowrot, Transnational Corporations as Steering Subjects in International 
While Lindahl suggests the richness of polycentric and intermeshing governance orders, Gunther Teubner has suggested the fecundity of governance forms out of crisis, catastrophe, and societal collision. ${ }^{264}$ I have been suggesting the power of normative systems, including those that produce the substantive values of self-constituting communities, as essential to the construction of a complex and networked system of poly-governance if human rights impacts individual or institutional actions. Those normative values, of course, are grounded in ideology, a necessity that I explored elsewhere. ${ }^{265} \mathrm{But}$ Teubner would go farther, suggesting in effect, that the addictive effects of ideology might well shape the nature of the behavior within and between systems. He has explored the possibility that systems, like individuals, can be organized as inherently addictive or at least prone to addictive behavior under certain conditions of stress. ${ }^{266}$

One could use these hypotheses as the foundation for an exploration of the character of compulsion, but Teubner has something else, something more interesting, in mind. He means to use the insights of systemic addiction to posit the way social systems approach catastrophe and transform themselves at the moment of disaster, not through the intervention of political actors, but autonomously and within the bounds of its own systemic logic. ${ }^{267}$ Not that this cyclical set of dialectical "moments" occur in isolation; rather, systemic addiction-as it reaches to and through the moment of confrontation with its own contradiction and reconstitutes itself to avoid obliteration-engages in these activities in constant communication with the economic and legal spheres. ${ }^{268}$ That inevitable systemic lurching toward catastrophe and its revaluing effects on the system itself, then, are communicated with and through the law and economic systems through which it interacts with business and the law-state. 269

Economic Law: Two Competing Visions of the Future?, 18 IND. J. GLOBAL LEGAL STUD. 803 (2011).

264. See Gunther Teubner, A Constitutional Moment? The Logics of 'Hitting the Bottom', in The financial Crisis In Constitutional Perspective: The Dark Side Of FUNCTIONAL DifFERENTIATION 3, 3 (Poul F. Kjaer et al. eds., 2011)

265. See Backer, supra note 36 .

266. See Teubner, supra note 267 , at 3 ("Is there such a thing as collective addiction?"). See also id. at 3-4 (explaining that self-destructive growth compulsion caused institutionalized systems, rationally organized, to act against their own interests).

267. Here, perhaps, is an ironic application of the parable found in Luke 4:23 ("Iatpé,

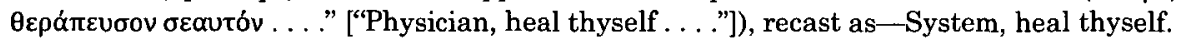

268. This, of course, was the essence of the communication of Apple, Inc. as it moved from isolated to more intermeshed systemic operation. See discussion, Section II.A., supra.

269. Yet, Nietzsche looms in the shadows. He reminds us that such communication can be inherently subordinating-another contradiction that itself is such to the cyclicity of dialectical system built on contradiction. In his exploration of the parameters of 
The addictive behavior of social systems embodies the contradiction built into the system itself. Catastrophe represents that moment when the self-organizing constitution of the social system is confronted in an unavoidable way with its destruction through the application of the logic of its own constitution. ${ }^{270}$ Catastrophe, in essence, provides a constitutional moment when the networked connection of communities of self-constituted organs exposes its connection in systems of capillary constitutionalism that transcend legal and economic codes and the borders of functionally differentiated governance organizations. ${ }^{271}$

Teubner starts with a search for the character of self-destructiveness in social systems-the root of its internal contradiction and the lubricant for its revaluation in the face of catastrophe. $272 \mathrm{He}$ criticizes the compartmentalized-and bureaucratic-approaches to a "solution" to the financial "based upon factor analysis, in which individual causes are isolated, through the attribution of causality, and held responsible for the crisis."273 $\mathrm{He}$ suggests a deeper analysis. Systemic addiction is understood within the context of social processes-as a phenomenology of communication. ${ }^{274}$ Teubner suggests communicative addiction as a compulsion to growth communicated through the mechanics of social interaction grounded in the dynamics of the production of money. ${ }^{275}$ This "raises a fundamental

punishment in the original connection of moral concept of guilt (Schuld) in the material concept of debt (Schulden), Nietzsche points to a variation of the notions of communication and hierarchy, as well as the contradiction and reconstitution of ideal and action. Guilt and Debt are built on principles of equivalence and transformation, that is, on the transposability of action, effect, and commodity. "And whence did ... this idea of an equivalence between injury and pain? I have already divulged it: in the contractual relationship between creditor and debtor, which is as old as the idea of 'legal subjects' and in turn points back to the fundamental forms of buying, selling, barter, trade, and traffic." FRIEDRICH NiETZSCHE, "Good and Evil," "Good and Bad", in ON THE GENEALOGY OF MORALS AND ECCE HOMO 24, 63 (Walter Kaufmann, ed. \& trans., R. J. Hollingdale trans., Vintage Books 1969) (1887).

270. See Teubner, supra note 219 , at 4 . This was the essence of the catastrophe facing Apple when caught in the contradictions of its own internally ordered system which defied efforts either to enforce or to explain to intermeshed stakeholder and autonomously operating systems. See discussion, Section II.A., supra.

271. See Teubner, supra note 219, at 4 . But this is neither Hegelian dialectics nor Marxist dialectical materialism, though both also reflect the cyclidity of systemic transformations lubricated by the contradictions built into social systems.

272. Id. at 5-10.

273. Id. at 5. I have suggested the same in the context of European efforts to assert regulatory power over irregular securities markets. See Larry Catá Backer, Monitor and Manage: MiFID and Power in the Regulation of EU Financial Markets, 27 Y.B. EUR. L. 349 (2008).

274. See Teubner, supra note 219 , at 6 .

275. See id. at 8. 
question for autopoietics: [h] ow are we to conceive of the relationship between social self-reproduction and the compulsion to growth?"276_-what I call the instinct toward managerialism..$^{277}$

A dynamic environment of self-reproduction of social systems must include both the equilibrium and destabilizing elements. Systems that do not embrace the logic of their own inversion, as compulsion, become irrelevant. ${ }^{278}$ Teubner recognizes that there is "an inherent compulsion to ever higher production in function systems other than the economy-an inherent compulsion which, on the one hand, is a necessary condition of self-reproduction, but which, on the other, can be propelled by assignable growth-inducing mechanisms to the point of transition into destructive tendencies." $279 \mathrm{He}$ notes that law systems are capable of creating conflict through their own regulation-that is that the law itself contains its own contradictions. ${ }^{280}$ Politics systems exhibit the same fundamental contradictory state; the movement toward the attainment of the fundamental objectives of such systems creates the conflicts that also distort the objectives and makes their attainment more difficult. To understand the distinction between normal growth-growth that does not threaten the stability of systems and their networks-from metastasizing growth that threatens stability,

276. Id. at 9 .

277. Yet, this suggests the possibility of a managerialism that is at variance with the foundational dynamic of the dialectic that Teubner identifies. That managerialism is considered in the consideration of self-destructive growth versus growth dynamics in communication. Id. at 7-10. Addictive behavior has a negative connotation, like the addictive imperatives of globalized capital considered earlier. These behaviors are destabilizing to individual and to system. They are also inherent in the body of the individual or system. The nature of addiction, after all, is its compulsiveness.

The definition of individual addiction-compulsive engagement in an activity despite lasting negative consequences-must be re-thought for social systems in general, and for collective actors in particular. Which 'addiction mechanisms' are responsible for the fact that the autopoietic self-reproduction of a social system through the recursivity of system-specific operations reverts into a communicative compulsion to repetition and growth, bringing self-destructive consequences in its wake?

Id. at 8. Yet this addiction, if Teubner is right, is also natural to the individual and system-without it, as Nietzsche reminds us, the dynamic element dissipates-no growth, no progress, no catastrophe bringing revaluation and transformation of the inner constitutions of systems.

278. This was certainly a lesson applied by Apple as it opened its governance framework to outside intermeshing and by that opening preserved its own integrity. See discussion, Section II.B., supra.

279. Teubner, supra note 219 , at 10 .

280. Id. at 11. 
Teubner turns to catastrophe-destabilization powerful enough to threaten systems. ${ }^{281}$

For that purpose, the analogy to cancer provides a powerful metaphor, and he invokes the idea of constitutional moments. 282 Teubner suggests a hybrid constitutionalization, in which a balance is reached between internal processes and external interventions in the process of reconstitution in the face of catastrophe. That is, a wall of external communication may be necessary to produce the boundaries within which self-reflectivity may serve to reconstitute systems in the midst of dynamic revaluation. ${ }^{283}$ Teubner suggests "not only state instruments of power, but also legal rules, and 'civil society' countervailing powers from other contexts, media, public discussion, spontaneous protest, intellectuals, social movements, NGOs or trade union power ... should apply such massive pressure on the function systems that internal self-limitations are configured and become truly effective."284 Thus, the task is to enlist the web of systems in their communicative interactions to foster interactions that provide a space within which any particular subsystem can construct its own stabilizing set of limits. The object is managerial and can be significant. "Political-legal regulation and external social influence are only likely to succeed if they are transformed into a self-domestication of the systemic growth dynamic. This requires massive external interventions from politics, law, and civil society: specifically, interventions of the type suited to translation into self-steering." 285

The difficulty, though, when dealing with social systems-for example the global economy-is that the character of the normative structure is complex. With a nod to both Derrida ${ }^{286}$ and Foucault, ${ }^{287}$ Teubner focuses on the capillary constitution-the microstructures of rules that constitute behavior values. This capillary constitution may

281. Id.

282. Id. at 10-21.

283. Id. This was nicely evidenced, of course, by the permeable barriers between Apple, Foxconn, and the outside certification organizations. See discussion, supra, Section II.

284. Id. at 13.

285. Id. at 15. Yet, as the Apple episode suggests, it can as well, in three-dimensional governance space also consist of massive interventions from other societally constituted organizations operating in nonstate governance space. See discussion, Section II.B., supra.

286. See generally JACQUES DERRIDA, THE OTHER HEADING: REFLECTIONS ON TODAY'S EUROPE (Pascale-Anne Brault \& Michael B. Naas trans., 1992) (1991) (describing how the European identity is changing through immigration and how that identity will have to adapt).

287. Michel Foucault, Räderwerke des Überwachens und Strafens: Ein Gespräch mit J.-J. Brochier [The Wheels of Monitoring and Penalties: A Discussion with J.-J. Brochier], in MIKROPHYSIK DER MACHT [THE MICROPHYSICS OF POWER] 31, 45 (Michel Foucault ed., 1976). 
not be managed directly - the tools of intervention are too crude for that purpose, but intervention may serve the same purpose as a grain of sand in an oyster-as an irritant that energizes the self-constituting mechanics of the subsystem in accordance with its own logic. 288

But this raises issues of method. For Teubner, this is the case of the Beelzebub casting out the devil. 289 The pattern of political constitutionalism might provide a loose template for managing societal capillary constitutionalism-that is for stabilizing systems grounded in the constitution of micro power. And what better notion than Rechtsstaat notion for that purpose-process as the bones of system constitution!
Just as in political constitutions power is used to limit power, so the system-specific medium must turn against itself. Fight fire by fire; fight power by power; fight law by law; fight money by money. Such a medial self-limitation would be the real criterion differentiating the transformation of the 'inner constitution' of the economy from external political regulation. ${ }^{290}$

This social system stability is not sourced within the state, but in three 'reflection centers' within society, and in particular, within economic institutions, into the criterion of a democratic society. Candidates for a capillary constitutionalisation exist not only in the organised sector of the global economy, in corporations and banks, but also in its spontaneous spheres."291 These collegial institutions "cultivate the relevant logic of actions, and [have required] them to be constitutionally institutionalised." 292 Here, one melds the utility of the

\footnotetext{
288. "The desired course for social sub-constitutions is, as has been said, in the limitations of the endogenous tendencies towards self-destruction and environmental damage. This is the core of the constitutional problematique, this difficult handling of the focal sub-system's self-transformation and that of their environmental systems." Teubner, supra note 219, at 15.

289. Id. at 16.

290. Id. at 17.

291. Id. (citations omitted).

292. Id. at 24 (citations omitted). This notion of collegial institutions as collective stakeholders in societal constitutionalism, even in the economic sphere, has found expression within the governance efforts of public institutions in the wake of the 2007 financial crisis. The Financial Stability Board system represents a public sector version of this naturalization of institutionalized communication within the economic sphere. See Larry Catá Backer, Private Actors and Public Governance Beyond the State: The Multinational Corporation, the Financial Stability Board, and the Global Governance Order, 18 IND. J. GLOBAL LEGAL STUD. 751, 784-91 (2011).
} 
topology of Hans Lindahl's "ought places" with Teubner's process of engagement for crisis and change.

Key for Teubner are "[t]he politicisation of consumers," "[t]he ecologisation of corporate governance," and "[p]lain money."293 The first concept evolves subsystem process to the construction and exercise of social preferences; the second concept broadens the impact of corporate constituencies within the governance structures and decision-making of economic entities; the third concept would add stability and order to the global financial constitution. ${ }^{294}$ The latter would require the reassertion of national power over the power to create money and money equivalents - the medium of economic exchange in its most liquid form.

Legal norms serve as both bridge and glue, joining autonomous systems.

A constitution is always the connection of two real ongoing processes. From the point of view of law, it is the production of legal norms, which is typically merged with the basic structures of the social systems. From the point of view of the social system, it is the generation of basic structures of the social order, which simultaneously inform the law and are regulated by it. ${ }^{295}$

But law serves a more important purpose: it becomes the source for closure, for the provision of a mechanics of stability. The stability provided by law is one that a social system, for example, the global economic system, may be incapable of providing under the logic of its own normative ordering. Law in this sense is both an ordering mechanism and an intervention to avoid the catastrophe of the self-destructive addictive tendencies of any system. ${ }^{296}$

293. Teubner, supra note 219 , at 17-19.

294. See id. Indeed, consumer and investor activism, expressed in buying and investment decisions, were central to Apple's actions, to the relationship between Apple and FLA, and ultimately between Foxconn and its employees. The irony is that labor, a direct stakeholder, could exercise a political role and precipitate a governance crisis within the Apple-Foxconn-China space only by their suicides. The more remote stakeholder tended to have greater political effect. See discussion, Section II, supra. Cf. Larry Catá Backer, From Moral Obligation to International Law: Disclosure Systems, Markets and the Regulation of Multinational Corporations, 39 GEO. J. INTERNAT'L L. 591-653 (2008).

295. Id. at 28 .

296. See id. at 29. And yet, as Section II suggested, in three-dimensional space, law's role may be played not by governance substitutes, but by monitoring and certification. $C f$. Larry Catá Backer, Global Panopticism: States, Corporations and the Governance Effects of Monitoring Regimes, 15 IND. J. GLOBAL LEGAL STUD. 101-48 (2008). 
That is the key to societal constitutionalism's addiction problem. Law as methadone- " $[t]$ he economy . . requires massive interventions from law in order to achieve self-constitutionalisation; albeit not to the comprehensive extent characteristic of politics." 297 There is a formalist cast to this constitution of societal systems undergirded by law. And not just governance, but connected by a more formal rule structure typical of the Rechtsstaat. "Through the restriction of money-creating competences, law apprehends the limitative function of an economic constitution and, at the same time, stabilises the self-reflexive relations of the payment operations, which, without being legally anchored in this way, would again disperse."298 I wonder, though, whether law, as Teubner understands it, is broad enough to include those techniques of behavior controlling power that serve Foucault's notions of governmentality. ${ }^{299}$

297. Teubner, supra note 219 , at 29.

298. Id. at 31 .

299. See Michel Foucault, Governmentality, in THE FoUCAULT EFFECT: STUDIES IN Governmentality 87, 102-03 (Graham Burchell, Colin Gordon \& Peter Miller eds., 1991) (describing governmentality as " $[\mathrm{t}] \mathrm{h}$ e ensemble formed by the institutions, procedures, analyses and reflections ... [t] $]$ he tendency which, over a long period and throughout the West, has steadily led towards the pre-eminence over all other forms . . . of this type of power ... [and] [t] he process, or rather the result of the process, through which the state of justice of the Middle Ages . . gradually becomes 'governmentalized."'). For a valuable analysis, see Wendy Larner \& William Walters, Global Governmentality: Governing International Spaces, in GLOBAL GovernMENTALITY: GOVERNING INTERNATIONAL SPACES 1, 16 (Wendy Larner \& William Walters eds., 2004) ("What we have called global governmentality entails a move of 'bracketing' the world of underlying forces and causes, and instead examining the different ways in which the real has been inscribed in thought."); Michael Reed, From the 'Cage' to the 'Gaze? The Dynamics of Organizational Control in Late Modernity, in REGULATION AND ORGANIZATIONS: INTERNATIONAL PeRsPeCTIVes 17, 43 (Glenn Morgan \& Lars Engwall eds., 1999) ("[B]ureaucratic control is giving way to a qualitatively different regime of control based on a contrasting trajectory and logic of regulative ordering in which intensive, but remote and dispersed, scanning of organizational behaviour and its 'normalizing' effects are the key features.").

Consider the complex of power issues involved in the construction of transnational transparency regimes of financial markets. Entities like the International Monetary Fund and World Bank "have found themselves drawn into battles with a range of transnational, multinational, domestic, and international authorities over the production of financial information and the diffusion of financial information." In this aspect, surveillance is felt as gouvernmentalité, a linking of governance with the techniques of its power.

Larry Catá Backer, Global Panopticism: States, Corporations, and the Governance Effects of Monitoring Regimes, 15 IND. J. GLOBAL LEGAL STUD. 101, 136-37 (2008) (citations omitted) (quoting Margaret Hanson, The Global Promotion of Transparency in Emerging Markets, 9 GLOBAL GOVERNANCE 63, 64 (2003) ("These political battles cast a critical light on seemingly apolitical assumptions that motivate much of the theoretical rationale for international governance strategies inspired by the goal of a transparent global financial system.")). 
But the notion of governmentality might require avoidance for another reason-it detracts from the larger project of securing recognition of the possibility of constitutionalism beyond the state. Teubner recognizes the skepticism within the academic herd, ${ }^{300}$ but he seeks to assuage them through mimicry, and thus the transposition of law and social system as basis of autonomous constitution (and emergence of autonomous constitutional code). ${ }^{301}$ In any case, it is not clear to me that the dynamics of the law-state ought to transpose to the social state. Here, Teubner's own resort to Foucault, and especially to notions of governmentality, might provide a useful insight. The construction of a constitutional code, understood in a systems way, might be understood as grounded in structural coupling of social system and governance code, built into the multiple fabrics of behavior managing systems, not law understood in its traditional form using the metrics of traditional constitutionalism. Understood in that way, the constitution of a global economy, founded on the communication among law-governance-politics systems and the establishment of governance rule hierarchy (constitutional code above the governance code from which it is derived and through which its elaboration is limited), becomes clearer and more powerful.

The communicative (structural coupling) aspect then comes to the foreground, tying into Teubner's notion of communication between systems as an irritant (and thus as a spur to internal change) and as an external limit on internal operation. ${ }^{302}$

These two types of programmes irritate one another to the point where they cause a specific co-evolutionary path of legal and economic structures within the economic constitution. . . Fundamental principles of the economic system are re-constructed as legal constitutional principles (according to the particular historical situation: property, contract, competition, social market economy or ecological sustainability). . . . In the opposite direction, something comparable occurs: the meta-code allows the re-entry of law into the economic system (again, historically variable: mandatory rules of contract law, the social obligations of property, the limits of competition, rule of law principles in economic decisions or fundamental rights within

300. I use the term here in its Nietzschean sense, though note an irony in applying Teubner's notion of self destructive compulsion to the herd habit.

301. Teubner, supra note 219, at 31-32.

302. Id. at 32-33. 
corporations). Thereby, constitutional law binds economic operations. ${ }^{303}$

We now understand the role of law sub-systems within the process of constitutional management as part of Teubner's construct, but what about political subsystems; what about the role of the state? "In the functionally-differentiated society, the political constitution cannot fulfill the role of defining the fundamental principles of other subsystems without causing a problematic de-differentiation-as occurred in practice in the totalitarian regimes of the twentieth century." 304 In place of hierarchy, Teubner offers communication as an action-inducing irritant and as autonomy. "We must give up the notion that, in the state, politics represents society and other social spheres-people or sub-spheres-participate therein. No social sub-system, not even politics, can represent the whole society." 305

But the economic system cannot play its role properly unless it too acquires it own autonomous politics. Here again is mimicry. A social system, like a law or political system requires its demos. And the actions of that demos constitutes legitimating acts and the preservation of autonomy within a system that preserves accountability. ${ }^{306}$ Again, structural mechanics are meant to manage the contradictions of systems that are inherently self destructive, as system, by providing webs and networks of restraint. ${ }^{307}$ But like political systems, that management of contradiction requires an outside force-systemic coupling and intermeshing produces the therapeutic results like that of

303. Id. at 33-34 (citations omitted).

304. Id. at 36 (citations omitted).

305. Id. at 37 .

306. This is the essence of the political concept of popular sovereignty in Western public law constitutionalism and political theory. See, e.g., EDMUND S. MORGAN, INVENTING THE PEOPle: The RIse of Popular Sovereignty IN ENGLAND AND AMERICA (1988). It also underlies the fundamental principle of the "mass line" in Marxist Leninist states like China. See Larry Catá Backer \& Keren Wang, State and Party in the Scientific Development of a Legitimate Rule of Law Constitutional System in China: The Example of Laojiao and Shuanggui (June 1, 2013), Conference: Rule of Law with Chinese Characteristics, Vol. 2013, at 101, Penn State Law Research Paper No. 26-2013, available at http://ssrn.com/abstract $=2273044$. That it can be transposed to societally constituted systems, like enterprises, merely reflects the parallels the similarity in constitution and organization, a central premise of this article.

307. See id. at 40-41. Of course, this was the essence of the position that Apple found itself in 2012, one that both produced the crisis (fear of a loss of legitimacy in the eyes of consumers, investors, and states) and its solution (by embedding their system within and among those of certifier organizations) which then strengthened the autonomy and coherence of Apple's societally-constituted organization as reflected in and through its structurally coupled governance universe. See discussion Section II.B, supra. 
the psychologist with the power to restrain and a set of therapeutic devices that the patient may use to self correct the contradictions of selfdestructive compulsion. ${ }^{308}$ For the financial system, that role would be served by an instrument of the law-state-the central banks. "Guardians of the constitution'-this is the appropriate metaphor. And just as constitutional assemblies and constitutional courts are the guardians of the political constitution, so the central banks and the constitutional courts are the guardians of the economic constitution. And their constitutional politics requires a high degree of autonomy." 309 However, effectiveness is possible only to the extent that these central banks attain a degree of autonomy from any one sector of the law-politics-economics troika.

\begin{abstract}
Here, the meaning of an autonomous financial constitution is revealed, which must control its own logic and cannot, despite its highly political character, be delivered by institutionalised politics. The analogy with constitutional courts is, again, appropriate. This is a principle not of the political, but of the societal separation of powers. ${ }^{310}$
\end{abstract}

Thus, Teubner draws this complex web together. All systems are subject to catastrophe as a function of the inherent contradictions of its own internal logic. Those contradictions are manifested (using the language of the therapeutic) in compulsive and self-destructive behavior which, given the internal logic of any system, can lead to catastrophe-the imperiling of system order itself.311 The self-destructive contradictions of all sub-systems (but, in this case, the economic social system) derived from the compulsions of its own internal logic can be managed. That management is inherent in the operation of the complex web of the troika law-politics-economics subsystems within which collective organs operate. ${ }^{312}$ Yet, no networked system can successfully project its power completely or thoroughly to reconstitute another. It may provide boundaries against the external effects of internal compulsion, and it may, acting within the constraints

308. This is the essence of the third party certification process-one of adoption of standards, internalization within an autonomous constituted system, and monitoring and assessment within the constraints of the standards developed to prop up systemic coherence. See discussion supra, Section II.B.

309. Teubner, supra note 219 , at 40-41.

310. Id. at 41 (emphasis removed).

311. Id.

312. Id. 
of its own logic, irritate internal reaction in other systems. ${ }^{313}$ But these irritants can be consciously applied and targeted. And thus, a simple irritant-the severe limitation on the power over money-is suggested as a means of working the machinery of networked sub-systems communicating with (irritating) each other and thus forcing internal confrontations with the illogic of internal constitutions before catastrophe manifests to threaten all sub-systems within the greater global social organ. ${ }^{314}$

Teubner has elaborated the possibility of order in the systems cosmos. He identifies the levers through which the system itself can face its self-destructive contradictions and compulsive addictions, while still avoiding excess and, at the same time, producing conditions that permit foundational revaluation in the face of the possibility of catastrophe. ${ }^{315}$ I wonder, though, whether fundamental systems order necessarily includes a large dose of chaos. It is not clear to me that the fundamental contradictions of systems-their relentless drive toward the limits of their logic; their compulsion to drive toward their limit, and, by such compulsion, to destroy their essence as they strive to attain it-is not both basic and inescapable. ${ }^{316}$

It is not the nearness of catastrophe, but catastrophe itself that provides the space within which a system either reengages in self-revaluation or is overtaken and reconstituted from outside. That is a possible lesson from the Great Depression of 1929. Teubner draws near that precipice and pulls back. But in that turn, he has illuminated

313. Id.

314. See id.

315. Gunther Teubner, A Constitutional Moment? The Logics of 'Hitting the Bottom,' in The Financial Crisis in Constitutional Perspective: The Dark Side of Functional DifFERENTIATION 3, 15-16 (Poul Kjaer, Gunther Teubner \& Alberto Febbrajo eds., 2011).

316. I wonder whether catastrophe is avoidable in the face of the inherent contradictions of systems, and the fundamental drive of systems to follow their internal logic (purity) to its limit (compulsion, addiction, crisis).

People, groups, all conscious organisms simultaneously seek the protection of oblivion, an acceptance of repose in some perfect and eternal state, equilibrium, on the one hand, and also struggle to overcome the desire for oblivion, that is struggle against faith. Such struggle leads to emancipation for those who can successfully struggle. That success is valid for those who struggle, but cannot be gifted to others. Each in turn must struggle-individual, group, organism-against the reality bequeathed to it. And thus the process of self-overcoming and recurrence are linked through death and transformation.

Larry Catá Backer, Cycles of Legal Foundations: Law After Deconstruction, LAW AT THE END OF THE DAY (Aug. 14, 2006, 1:44 PM), http://cbackerblog.blogspot.com/2006/08/cyclesof-legal-foundations-law-after.html. This suggests an ancient insight into the cyclicity inherent in systems. See generally IBN KHALDUN, THE MUQADDIMAH: AN INTRODUCTION To History (Franz Rosenthal trans., Princeton Univ. Press 2d ed. 1967) (1377). 
an elegant and plausible basis for management, far more coherently drawn than the limited scope approaches that have been the bread and butter of financial sector analysis since the recognition of the slide toward financial sector catastrophe in 2007. It is in this sense that Ino Augsberg's insight about the role of interpretation of systemic text-as a form of structural coupling-can be usefully understood:

Law's function is then no longer primarily to guarantee unity, but rather to guarantee difference. Luhmann's theory of fundamental rights can serve as an example of this kind of legal theory. Under circumstances in which society has 'dynamized its restabilization process, so that change has become a constant,' the specifically legal activity, understood as a social immune system, has to reprogram its immune reactions so that they focus more on protecting diversity and variation. ${ }^{317}$

It is also in this context that Marc Amstutz's ${ }^{318}$ insights about the way in which legal systems adapt to their social environments can, in turn, be adapted to the governance system of nonstate actors. ${ }^{319}$ "Self-organizing values deriving from legal policy, on the one hand, social responsiveness through the plasticity of the normative elements woven into a legal system, on the other-these, in a nutshell, are the conditions for evolvable, time-binding law."320 This produces both a move toward constitutionalization as a self-referencing structure (preserving stability) ${ }^{321}$ and a privileging of norm certainty in text. ${ }^{322}$ These insights must be adapted precisely because they remain twodimensional. That two dimensionality is grounded in the embrace of the law-state system and the hierarchy of law as the prism through which

317. Augsberg, supra note 75, at 386-87 (citations omitted).

318. Marc Amstutz, Biography, HIL, LAW OF THE FUTURE FORUM, http://www.lawofthe future.org/167/ (last visited Aug. 17, 2013) ("Marc Amstutz is Professor of Commercial Law, Legal Theory and Sociology of Law at the University of Freiburg. He is a member of the executive board of the German Association for Law \& Society (Vereinigung für Recht und Gesellschaf) and co-founder of the Institut für Recht und Wirtschaft (IDÉ) at the University of Freiburg where he is executive director.")

319. Marc Amstutz, Global (Non-)Law: The Perspective of Evolutionary Jurisprudence, 9 GERMAN L.J. 465 (2008).

320. Id. at 474 (2008) (citation omitted).

321. "These rules on rules must not only be capable of reacting to unforeseen cases, that is, to provide guidance as to how new law is to be created; the rules on rules must also assure the finitude of the adjudication process." Id. at 475 (citation omitted).

322. "Only textuality can ensure that a rule is responsive for social evolution." Id. (citation omitted). 
systemic relationships are understood..$^{323}$ With a focus on the relationship of the autonomy of law and society, the nature of regulatory relationships posit a singular layer-that between society as a singular amalgam and law, bounded up in states. ${ }^{324}$ That is a useful framework for understanding the relationship between these organisms around which political society was organized through the end of the $20^{\text {th }}$ century through structural coupling grounded in the semiotics of communication among a single set of core actors and a single set of signs. ${ }^{325}$ But it does little to suggest the ways in which this relationship is itself embedded, and increasingly so within a world structured on the free movement principles of globalization, among governance systems and the multiple social organisms through which they are expressed, including the state and society, but also international public organizations, civil society, religion, and economic enterprises. It also does little to indicate the ways in which the technologies of regulation have themselves changed the architecture of regulatory systems. ${ }^{326}$

What emerges from the application of these insights drawn from theory to the reality suggested by Apple, Inc., is the antithesis of orderliness, unity, and linearity of conventional constitutionalism. Societal constitutionalism is marked by four fundamental characteristics that also define the constitutional element of the structure of global law of which societal constitutionalism forms a part. ${ }^{327}$ These four-fracture, fluidity, permeability, and polycentricity ${ }^{328}$-both structure the dynamic governance space to which even states are now bound, and also forms the essence of the premises

323. See, e.g., Marc Amstutz, The Letter of the Law, 10 GERMAN L.J. 357 (2009).

324. "One spectacular example of text fluctuations is the écriture of the BGB, which was applicable law in an empire, throughout the Weimarer parliamentarianism, in the fascist regime of the Third Reich, in the Bonn Republic, and finally also in reunited Germany." Id. at 373 .

325. Id. ("the boundaries of the semantic identity of signs are functions of an open system of permanent re-differentiation ... which makes it possible to change meanings when signs are repeated, and ... the possibility for society to give Law constant measure and to determine the modulating legal language game.")

326. See Vaios Karavas, The Force of Code: Law's Transformation Under Information-Technological Conditions, 10 GERMAN L.J. 463, 478-80 (2009). The discussion of calculable normativity first considered in Vaios Karavas \& Gunther Teubner, http://www.Company NameSucks.com: The Horizontal Effect of Constitutional Rights Against "Private Parties" within Autonomous Internet Law, 4 GERMAN L.J. 1335, 1347 (2003) suggests both the transformation and limited context within which traditional structural coupling tethered to the law-state system is understood and studied.

327. Backer, supra note 44 (arguing that four characteristics create "the fundamental structure of global law ... [and] serve as the structural foundations of its constitutional element, its substantive element, and its process element").

328. Id 
that guide the self-constituting behaviors of nonstate actors like Apple, Inc. Fracture is certainly well understood within now classic societal constitutionalism. ${ }^{329}$ Fracture suggests a reordering rather than an end of order and the emergence of multiple, uneven, and functionally distinct governance communities that slide over, through, and within a set of unchanging objects and subjects of governance-consumers, investors, citizens, and "those norms that structure and organize fracture in a world order populated by an aggregate of a large variety of governance organs with territorial boundaries that vary with the variation in the character of the governance organization." 330 Apple, Inc. is operated in a governance space marked by fracture-between the laws of home and host states, between international law and norms, among its own operating governance rules and those of its downstream supplier, and near the rules of third party private accrediting units from which it buys legitimacy among public and private constituencies. ${ }^{331}$

Beyond fracture there is fluidity, "based on the assumption that governance organizations are impermanent and that there is no need to organize a meta-system around the premise that once established, self-constituted organizations ought to be preserved."332 Fluidity suggests the opposite of governance equilibrium and stability. It posits that governance systems move with the borders and tastes of the constituting agents. ${ }^{333}$ It suggests temporality as a significant factor in self-reflexivity. Governance units do not exist outside of history, nor do they exist outside the logic of the ideology of mass movements that now serve to frame governance. Fluidity suggests the permanence of the norms within which governance is effectuated but not the functionally differentiated organs the objective of which is to increase the welfare of their participants within those norms. ${ }^{334}$ Fluidity was central to Apple's governance environment-with a changing architecture of governance grounded in a more stable system of norms tied to the desires of critical stakeholders, consumers, and investors, and subject to the incomplete interventions of states.

Fluidity suggests the porosity that is a characteristic of systems operating in a fractured governance space. This is the realm of

329. See, e.g., Fischer-Lescano \& Teubner, supra note 16, at 1017-44 (identifying "[t]hree guiding principles for the decentralized networking of legal regimes").

330. Backer, supra note 44, at 187.

331. See discussion at Section II, supra.

332. Backer, supra note 44, at 188.

333. Id.

334. This suggests the medieval distinctions between gubernaculum and jurisdictio, the administration of the apparatus of government and the overarching normative framework within which those operate. Cf. Larry Catá Backer, Reifying Law-Government, Law and the Rule of Law in Governance Systems, 26 PENN ST. INT'L L. REV. 521, 522 (2008). 
structural coupling, but not of communication in its two-dimensional context-permeability suggests a porosity of systems in paradox. ${ }^{335}$ The more open the system is to inter-systemic penetration, the more stable and structurally sound the system. Societal constitutionalism reconceives borders as divisions that separate but do not impede. Apple, Inc. was at the center of a set of systems that projected themselves in and through each other, and yet, by that projection, each system preserved and solidified its integrity even as it opened itself to reaction from the penetration. Apple's relationship with national law (United States and China), international norms, the norms of the Fair Labor Association, all contributed to or affected the regulatory relationships between Apple and its suppliers and became critical in the construction and maintenance of Apple's autonomous governance structures for supplier behavior. Apple maintained the structural autonomy of its own supplier governance even as that governance was substantially affected by interventions from other governance units. The techniques of structural coupling - and its dynamics - are at the center of Teubner's notions of irritants and cyclicity, but the intervention cycles now operate in a deeper space: "governance not only serves as a signifier of a space that exists outside of the state-government master construct, but also in intimate connection with it." 336

Fluidity and porosity in fractured space do not operate seriatim-they function simultaneously throughout governance space; that space is polycentric space. "If law is no longer the only authentic and legitimate means of effectuating governance systems, and if states are no longer necessarily the principal and superior organization for the management of behavior, it may also follow that governance can exist in multiple locations simultaneously." 337 Polycentricity sets societal constitutionalism in motion-constant motion. To some extent, it suggests the focus on collaborative governance among multiple governance stakeholders that is the hallmark of the "New Governance" advocates. ${ }^{338}$ But it also suggests collision as much as collaboration and

335. See Backer, supra note 44.

336. See Backer, supra note 36, at 106 (citing James N. Rosenau, Governance, Order, and Change in World Politics, in GOVERNANCE WITHOUT GOVERNMENT, supra note 122, at 1). See generally COMPLEX SOVEREIGNTY: RECONSTITUTING POLITICAL AUTHORITY IN THE TwEnTY-First CENTURY (Edgar Grande \& Louis W. Pauly eds., 2005); ProsPeCTs of LeGAL SEMIOTICS (Anne Wagner \& Jan M. Broekman eds., 2010).

337. Backer, supra note 44 , at 196.

338. E.g., Julia Black, Decentring Regulation: Understanding the Role of Regulation and Self-Regulation in a 'Post-Regulatory' World, in 54 CURRENT LEGAL Problems 103, 108 (M. D. A. Freeman ed., 2002) ("Regulation therefore cannot take the behaviour of those being regulated as a constant. Regulation is . . the 'conduct of conduct', or . . 'to act upon action.") (citations omitted); Jody Freeman, The Private Role in Public Governance, 75 
irritation as much as harmonization. ${ }^{339}$ Apple, Inc. provides a case in point-it is operating within and against multiple governance systems with shifting authority and contributing to the polycentric irritation for its own downstream supplier Foxconn, which also faces similar irritations to its own societally constituted system, but one in a relationship that that of Apple which is vertically arranged.

Together, this suggests a dynamic element to societal constitutionalism that may help to explain - by the focus on constituted societies within complexes of such entities-both the nature of constitutive autonomy and the character of communication that, while internalized, does not necessarily suggest a threat to or insufficiency of separation from other governance bodies. This indicates intermeshing beyond networking, irritation, and permeability. ${ }^{340}$ It suggests instead the simultaneous operation of multiple interpenetrations of systems that remain stable only within a fluid context of constant communication framed by the desires of overlapping stakeholders that find expression through action (voting, consuming, investing, assessing, reporting, etc.). This produces a regulatory polycentricity that is itself dynamic among interacting and dynamically constituted societal organizations, all of which then intermesh with public bodies, including the state. These are the lessons that were illustrated by Apple, Inc. in Section II, as it sought to protect its self constitution in the face of crisis in a shared governance space. These lessons, in turn, may well provide a basis in theory for understanding phenomena, like that of the governance structures of Apple, Inc., that gets us closer to conforming our theory-ideology to the realities around us. The dynamic element of societal constitutionalism, especially for nonstate governance organizations, solves the difficulty of a static view of societal constitutionalism-the logic of autonomy within self-constituting societies that do not have either territory or broad function that operate in a space in which states continue to assert a broad authority, but in which other actors also intervene beyond and among states.

N.Y.U. L. REV. 543, 550-56 (2000) (negotiated rulemaking); Elinor Ostrom, Beyond Markets and States: Polycentric Governance of Complex Economic Systems, 100 AM. ECON. REV. 641, 641 (2010) ("Scholars are slowly shifting from positing simple systems to using more complex frameworks, theories, and models to understand the diversity of puzzles and problems facing humans interacting in contemporary societies.").

339. See Larry Catá Backer, On the Evolution of the United Nations' "Protect-Respect-Remedy" Project: The State, the Corporation and Human Rights in a Global Governance Context, 9 SANTA CLARA J. INT'L L. 37, 73.77 (2010) (discussing "[t]he corporate responsibility to respect human rights").

340. Cf. Teubner, supra note 118, at 212-13 (discussing the factors necessary for the success of corporate codes). 


\section{CONCLUSION}

"In 1973 Niklas Luhmann could still assert that a radical change in the state of the constitution and the institutional and operational understanding of constitutional arrangements comparable to the establishment of the constitutional state in the 18th century has never occurred again." 341 This radical change has since occurred. Constitutionalism has become something more than a means to deepen the logic of the state system upon which much of constitutional development was based. Having served as a template for the "perfectable" state, it has become the framework for judging the legitimacy and value of all constituting societies. The various settlements of the aftermath of the second World War were meant to institute an international system that would protect the state system, now tamed by an appropriate foundation of substantive values. But the system that it created-public and international on the one hand, and private and globalized, on the other-gave rise to fracture of governance even as it provided a basis for the protection of the state system. In effect, globalization and the internationalization of law extended the space for governance. States continue to exist as they did, but governance now has become institutionalized beyond the frontiers of the traditional jurisdictions of states. "The history of modernity has been that of increasing complexity in the patterns of social and economic organization, defiant of singular or all-embracing solutions. . . . Yet, in much of our thinking, we continue to believe that society can somehow be governed or steered." 342

This article considered the consequences of this emerging framework of hierarchical power arrangements and horizontal effects for constitutional theory among this amalgam of states and other societally constituted organisms in three-dimensional space. Section I engaged in framework setting, focusing on the structures of societal constitutionalism within the logic of globalization. This consideration necessarily frames societies and their constitution from a spatially static and inward-looking perspective. That investigation first considered societal constitutionalism as a set of parameters for the ordering system of states and nonstate actors and then the organization of corporate actors within this framework in the context of the human rights impacts of corporations. Section II considered these constituted societies in a more dynamic and outward-looking perspective. The

341. Grimm, supra note 30 , at 71 .

342. Ash Amin \& Jerzy Hausner, Interactive Governance and Social Complexity, in BEYOND MARKET AND HIERARCHY: INTERACTIVE GOVERNANCE AND SOCIAL COMPLEXITY 1, 1 (Ash Amin \& Jerzy Hausner eds., 1997). 
episode of Apple, Foxconn and the worker suicides suggest not merely two dimensional space-the structural coupling and intermeshing among self-referential societally-constituted entities and states, but rather a three-dimensional space in which hierarchies might exist in all directions among clusters of states, nonstate self-constituted actors and other organisms that produce and monitor governance. If societies can be understood as subject to certain principles for their inward constitution, to what extent might there be principles that affect the outward expression of inward self-constitution, especially when that direction is not merely "up" and "down" a two dimensional hierarchy? That consideration requires both an examination of the way in which societally constituted entities may be felt and seen by outsiders, but also the way that expressive communication can have inward affecting consequences. For that purpose, Gunther Teubner's notions of addiction and chaos and Hans Lindahl's notions of spatiality and communication serve as a starting point.

Section III had as it subjects the consideration of the theoretical consequences of the realities explored earlier. What in Section I appeared as little more than the expansion of the family of self-constituted actors becomes, in Section II, a polycentric mass that not just communicates but collides, conflicts, and affects the external extent of governance spaces and the internal organization of those spaces. The context is the enforcement of international human rights norms through the governance activities of Apple Inc. and its supply chain. The focus is the spaces where systems converge, harmonize, and collide. But Section III suggested theoretical order to the chaos, and a structure that extends and generalizes the particular factual context of Apple's crisis and its resolution.

Section III suggested the need to expand our understanding of constitutional theory beyond incarnation and judgment, to include communication among systems in a complex polycentric constituting universe in which territory remains an essential feature of systemic differentiation, but the character of territory becomes substantially more mutable. The conclusion is one that fundamentally shifts the focus of Ralf Michael's brilliant analysis of lex mercatoria ("the lex mercatoria without a state remains within a state-focused legal paradigm") ${ }^{343}$ - the societal constitution beyond the state remains engaged by and with the state and is not absorbed within a state-focused legal paradigm. The article thus concludes where it started-in constitutional theory. Now liberated from the state, and its theoretical constraints, and of the public-private binary that also privileges the state (and law) as the

343. Michaels, supra note 116 , at 452. 
center of constitutional analysis, societal constitutionalism is put in motion that oscillates rather than moving back and forth between public and private spheres.

In his 1920 Hibbert lectures on "The State, Visible and Invisible,"344 the English author, Anglican prelate, and professor of Divinity at Cambridge, William Ralph Inge, criticized the deification of the state qua state. But in a moment of prescient clarity logic took him further:

We are perhaps on the threshold of an epoch in which other associations, either wider than the nation, like the Catholic Church, or Labor, or narrower than the nation, like the groups which it is proposed to form into trade guilds, may claim and receive the same immoral and unquestioning devotion which, when given to the State, has brought such hideous calamities upon the world. If so, we shall find that the error is not less destructive in its new forms. ${ }^{345}$

We have arrived at such an age. Whether, indeed, the multi-spatial and polycentric governance frameworks of a world structured on principles of societal constitutionalism will live down to Dean Inge's vision remains to be seen, but what is clear is that the transformation from the monotheism of state worship to the more complex paganism of the modern age of government without the state will surely reshape the relationships between individuals and governance organs.

344. William Ralph Inge, The God-State, in LEviathaN IN CRISIS: AN INTERNATIONAL Symposium on the STATE, ItS PASt, PRESENT, AND Future, By FifTY-Four Twentieth Century Writers 150, 150 (Waldo R. Browne ed., 1946).

345. Id. at 153 . 
